University of South Florida

DIGITAL COMMONS

Digital Commons @ University of

@ UNIVERSITY OF SOUTH FLORIDA

South Florida

USF Accountability Reports

USF Archives

$1-1-2011$

\title{
2011 Annual Report USF System
}

USF

Follow this and additional works at: https://digitalcommons.usf.edu/usf_accountability_reports

\section{Scholar Commons Citation}

USF, "2011 Annual Report USF System" (2011). USF Accountability Reports. 19.

https://digitalcommons.usf.edu/usf_accountability_reports/19

This Article is brought to you for free and open access by the USF Archives at Digital Commons @ University of South Florida. It has been accepted for inclusion in USF Accountability Reports by an authorized administrator of Digital Commons @ University of South Florida. For more information, please contact digitalcommons@usf.edu. 
Data definitions are provided in the Appendices.

\footnotetext{
Note concerning data accuracy: The Office of the Board of Governors believes that the accuracy of the data it collects and reports is paramount to ensuring accountability in the State University System. Thus, the Board Office allows university resubmissions of some data to correct errors when they are discovered. This policy can lead to changes in historical data.
} 


\section{TABLE OF CONTENTS}

Dashboard. page 1

Key Achievements ..page 5

Narrative Report. page 6

Data Tables page 13

\section{Section 1 - Financial Resources}

[Not every university will have HSC \& IFAS tables.]

TABLE 1A. University Education and General Revenues

1B. University Education and General Expenditures

1C. State Funding per Full-Time Equivalent (FTE) Student

1D. University Other Budget Entities

1E. University Total Revenues and Expenditures

1F. Voluntary Support of Higher Education

1G. University Federal Stimulus Dollars (ARRA)

1H. HSC - Education and General Revenues

1I. HSC - Education and General Expenditures

1J. HSC - Faculty Practice Plans

1K. IFAS - Education and General Revenues

1L. IFAS - Education and General Expenditures

\section{Section 2 - Personnel}

TABLE 2A. Personnel Headcount

\section{Section 3 - Enrollment}

TABLE 3A. University Full-Time Enrollment (FTE)

3B. Enrollment by Location

\section{Section 4 - Undergraduate Education}

TABLE 4A. Baccalaureate Degree Program Changes in AY 2009-2010

4B. First-Year Persistence Rates

4C. Federal Definition - Undergraduate Progression and Graduation Rates for Full-Time,

First-Time-in-College (FTIC) Students
Section 4 - Undergraduate Education (continued)

TABLE 4D. SUS Definition - Undergraduate Progression and Graduation Rates for Full- \& Part-Time, First-Time-in-College (FTIC) Students

4E. SUS Definition - Undergraduate Progression and Graduation Rates for AA Transfer Students

4F. SUS Definition - Undergraduate Progression and Graduation Rates for Other Transfer Students

4G. Baccalaureate Degrees Awarded

4H. Baccalaureate Degrees Awarded in Areas of Strategic Emphasis

4I. Baccalaureate Degrees Awarded to Underrepresented Groups

4J. Baccalaureate Completion Without Excess Credit Hours

4K. Undergraduate Course Offerings

4L. Faculty Teaching Undergraduates

4M. Undergraduate Instructional Faculty Compensation

4N. Student/Faculty Ratio

4O. Professional Licensure Exams - Undergraduate Programs

4P. Tuition Differential Fee

\section{Section 5 - Graduate Education}

TABLE 5A. Graduate Degree Program Changes in AY 2009-2010

5B. Graduate Degrees Awarded

5C. Graduate Degrees Awarded in Areas of Strategic Emphasis

5D. Professional Licensure Exams - Graduate Programs

\section{Section 6 - Research and Economic Development}

TABLE 6A. Research and Development

6B. Centers of Excellence

6C. State University Research Commercialization Assistance Grants

6D. 21st Century World Class Scholars Program 


\begin{tabular}{|c|c|c|c|c|c|c|c|}
\hline \multicolumn{8}{|c|}{ University of South Florida 2011 Dashboard } \\
\hline \multicolumn{3}{|c|}{ Sites and Campuses } & \multicolumn{5}{|c|}{ USF Tampa Campus, USF St. Petersburg Campus, USF Sarasota-Manatee Campus, USF Polytechnic Campus } \\
\hline Enrollments & Headcount & $\%$ & \multicolumn{3}{|c|}{ Degree Programs Offered (As of Spr. 2011) } & \multicolumn{2}{|c|}{ Carnegie Classification } \\
\hline TOTAL & \multirow{2}{*}{47,800} & \multirow{2}{*}{$100 \%$} & \multirow{2}{*}{\multicolumn{2}{|c|}{ TOTAL }} & \multirow{2}{*}{224} & \multirow{2}{*}{$\begin{array}{l}\text { Undergraduate } \\
\text { Instructional Program: }\end{array}$} & \multirow{2}{*}{$\begin{array}{c}\text { Balanced arts \& sciences/professions, } \\
\text { high graduate coexistence }\end{array}$} \\
\hline (Fall 2010) & & & & & & & \\
\hline Black & 5,136 & $11 \%$ & \multicolumn{2}{|c|}{ Baccalaureate } & 84 & \multirow{2}{*}{$\begin{array}{l}\text { Graduate Instructional } \\
\text { Program: }\end{array}$} & \multirow{2}{*}{$\begin{array}{l}\text { Comprehensive doctoral } \\
\text { with medical/veterinary }\end{array}$} \\
\hline Hispanic & 6,897 & $14 \%$ & \multicolumn{2}{|c|}{ Master's \& Specialist's } & 98 & & \\
\hline White & 30,073 & $63 \%$ & \multicolumn{2}{|c|}{ Research Doctorate } & 39 & Enrollment Profile: & High undergraduate \\
\hline Other & 5,694 & $12 \%$ & \multicolumn{2}{|c|}{ Professional Doctorate } & 3 & Undergraduate Profile: & $\begin{array}{l}\text { Medium full-time four-year, selective, } \\
\text { higher transfer-in }\end{array}$ \\
\hline Full-Time & 32,165 & $67 \%$ & \multirow{2}{*}{ Faculty (Fall 2010) } & \multirow{2}{*}{$\begin{array}{l}\text { Full- } \\
\text { Time }\end{array}$} & \multirow{2}{*}{$\begin{array}{l}\text { Part- } \\
\text { Time }\end{array}$} & Size and Setting: & Large four-year, primarily nonresidential \\
\hline Part-Time & 15,635 & $33 \%$ & & & & \multirow{2}{*}{ Basic: } & \multirow{2}{*}{$\begin{array}{c}\text { Research Universities } \\
\text { (very high research activity) }\end{array}$} \\
\hline Undergraduate & 36,292 & $76 \%$ & TOTAL & 1,665 & 476 & & \\
\hline Graduate & 9,415 & $20 \%$ & Tenure/T. Track & 1,142 & 79 & \multirow{2}{*}{$\begin{array}{l}\text { Community } \\
\text { Engagement: }\end{array}$} & \multirow{2}{*}{$\begin{array}{l}\text { Curricular Engagement andOutreach and } \\
\text { Partnerships (Tampa and St. Pete) }\end{array}$} \\
\hline Unclassified & 2,093 & $4 \%$ & Other Faculty/Instr. & 523 & 397 & & \\
\hline
\end{tabular}

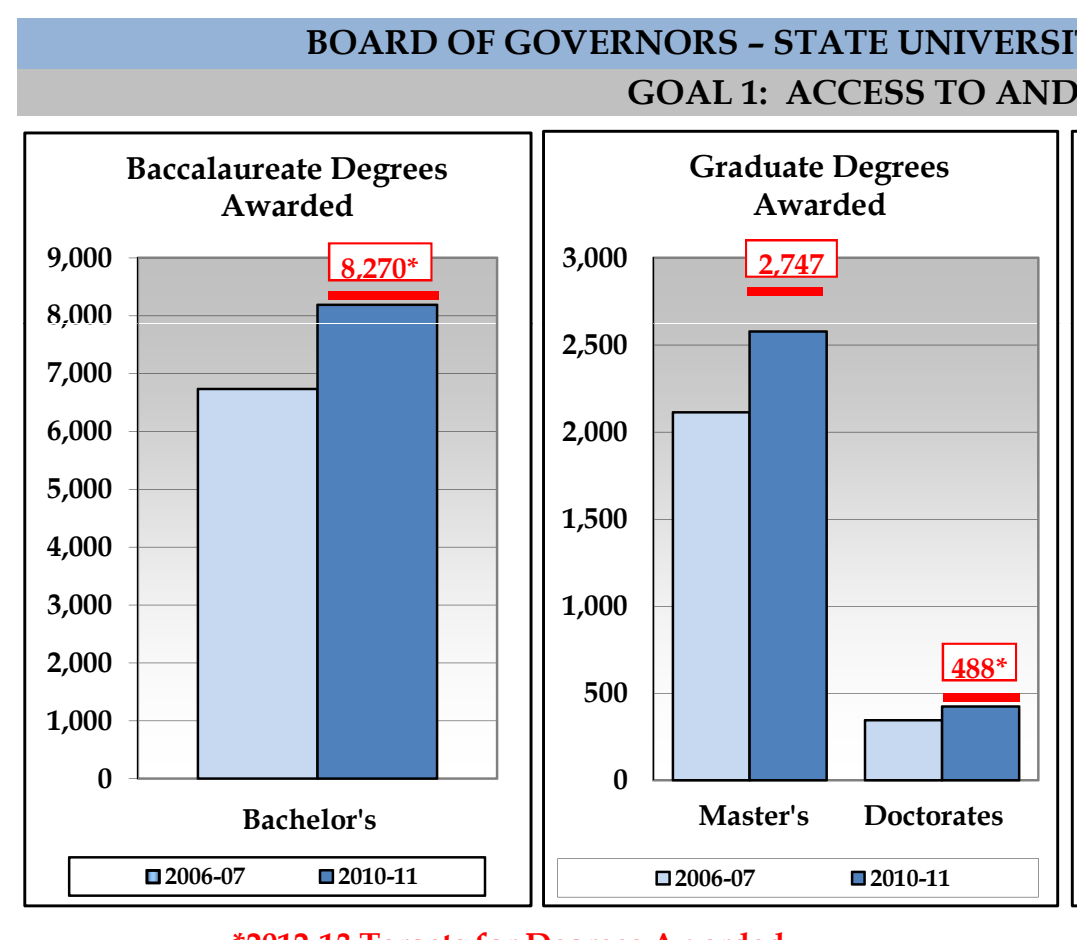

*2012-13 Targets for Degrees Awarded.

Note: All targets are based on 2010 University Workplans.

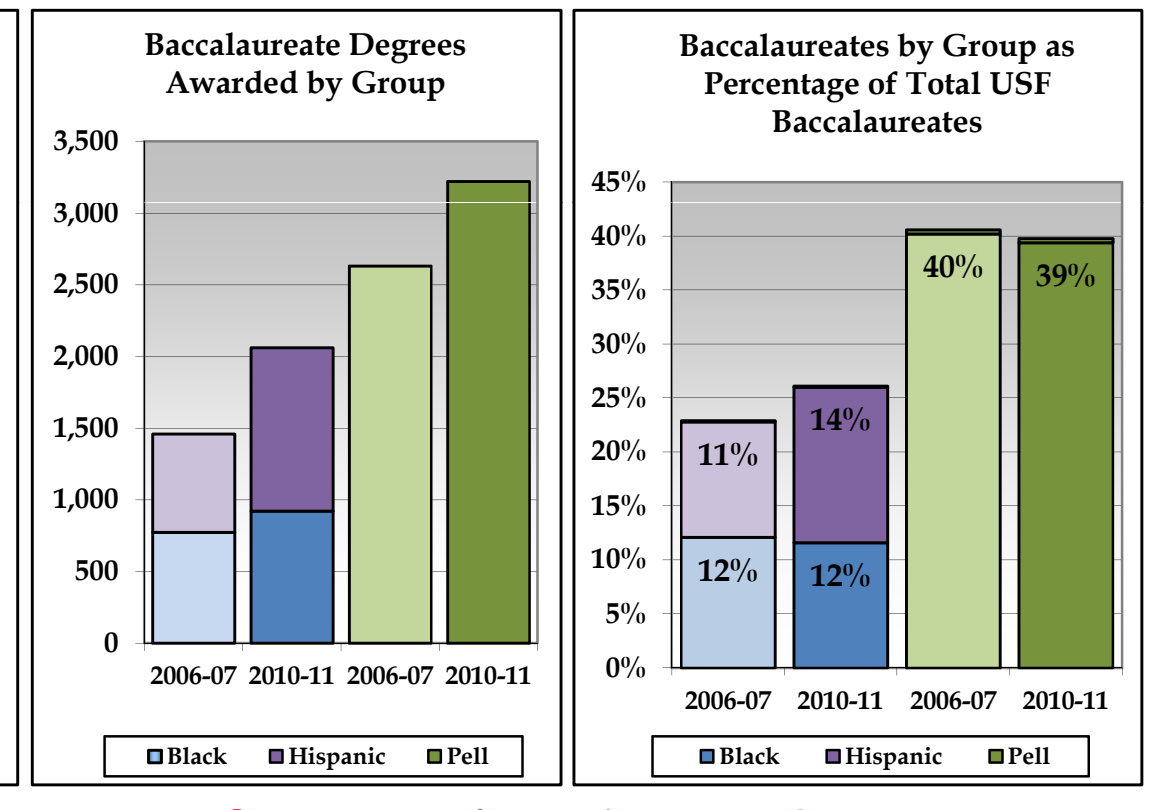

[2012-13 Targets for Baccalaureates By Group Reported in Volume II - Table 4I.]. 


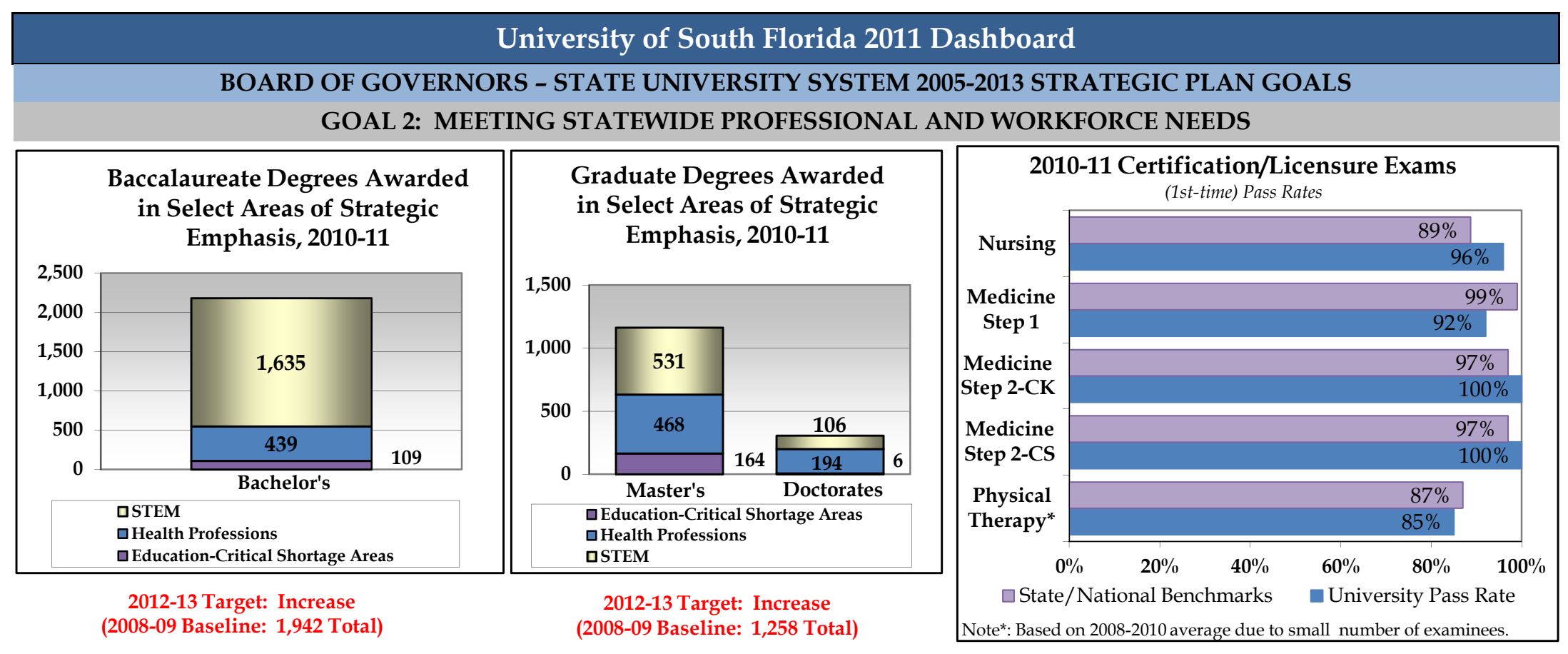

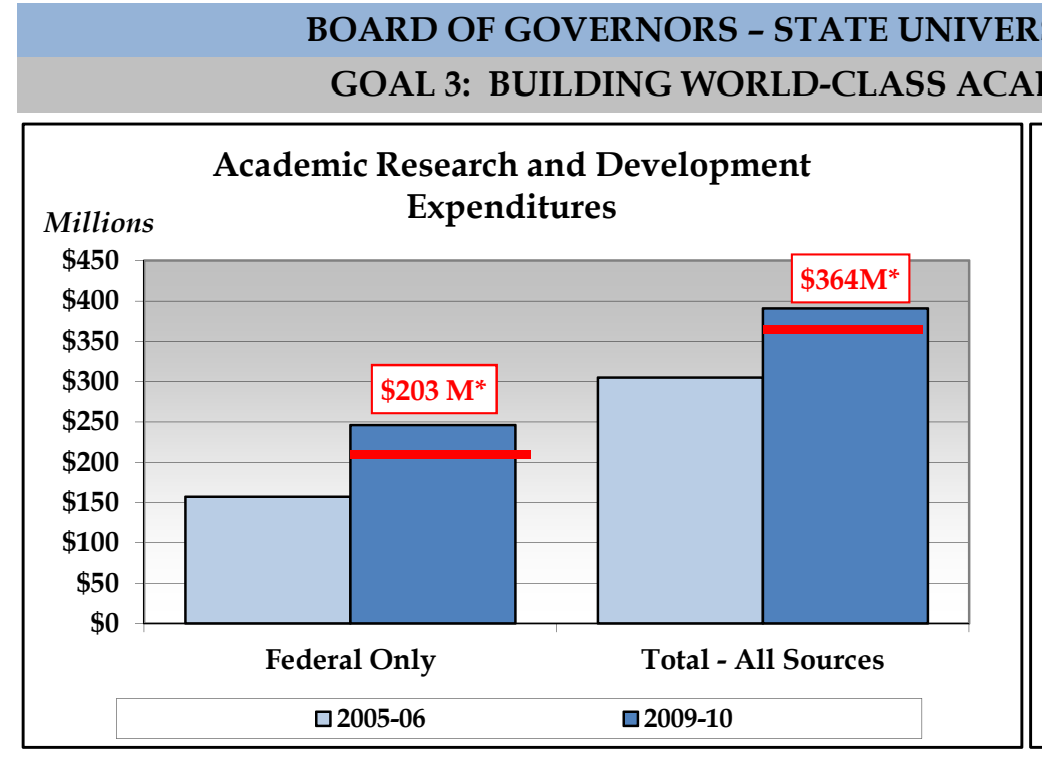

*2011-12 Targets for Research \& Development Expenditures.

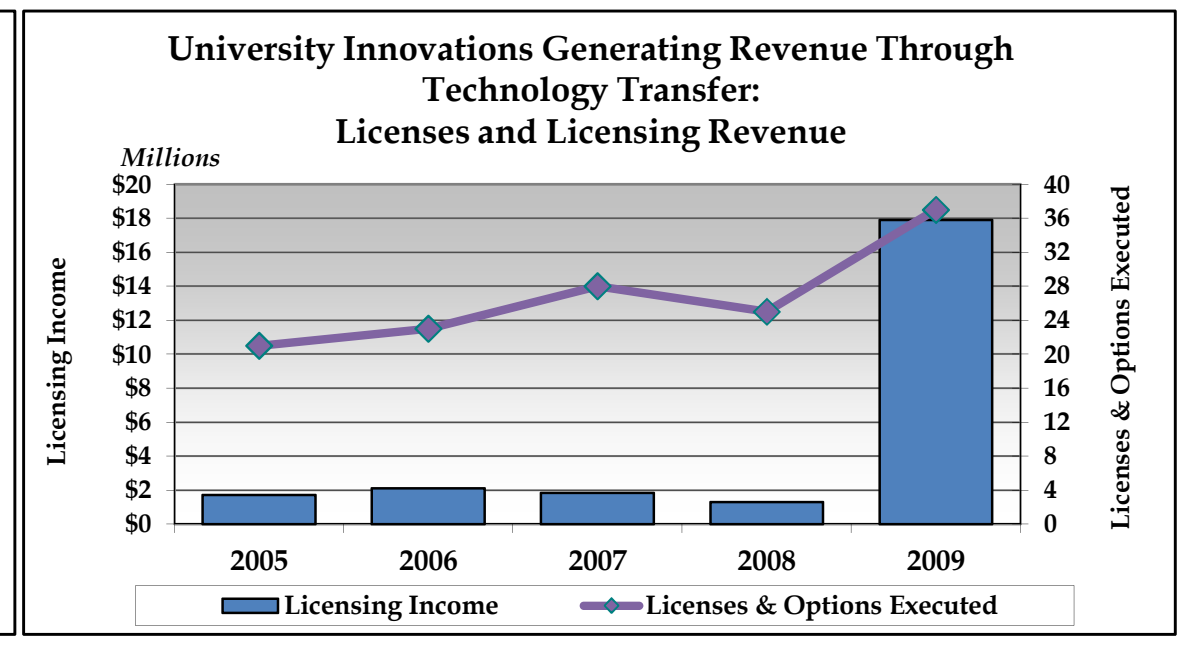

2011-12 Targets: Licenses - Increase (2008 Baseline $=23$ ) Licensing Revenue - Increase (2008 Baseline $=\$ 2,099,712)$ 


\section{New Florida}

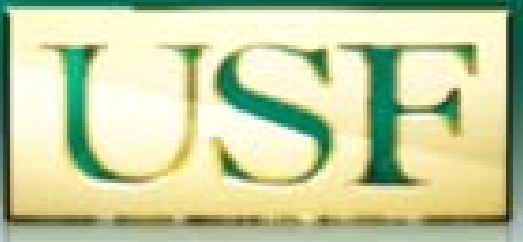

\section{State Goals - USF}

$41 \%$ of 10,835 degrees awarded by USF are in SUS

"Areas of Strategic Emphasis"

\section{Engaged Students}

- Carnegie designation for Tampa and St.

Petersburg as community engaged

- USF ranked $8^{\text {th }}$ among 4,000 for commitment to student veterans

- $41.1 \%$ of USF BA/BS grads had Pell grants

- Of 250,000 alumni, $76 \%$ stayed in Florida

- College of Education - Hillsborough Schools' \$100m Gates grant

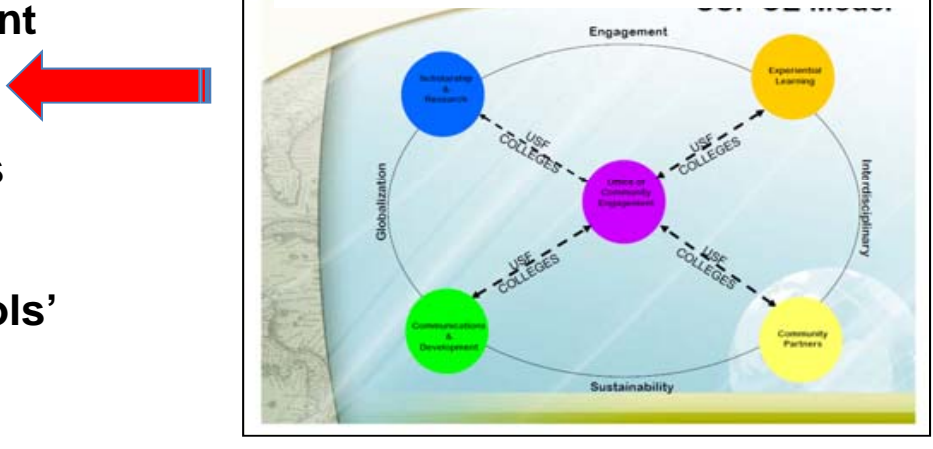




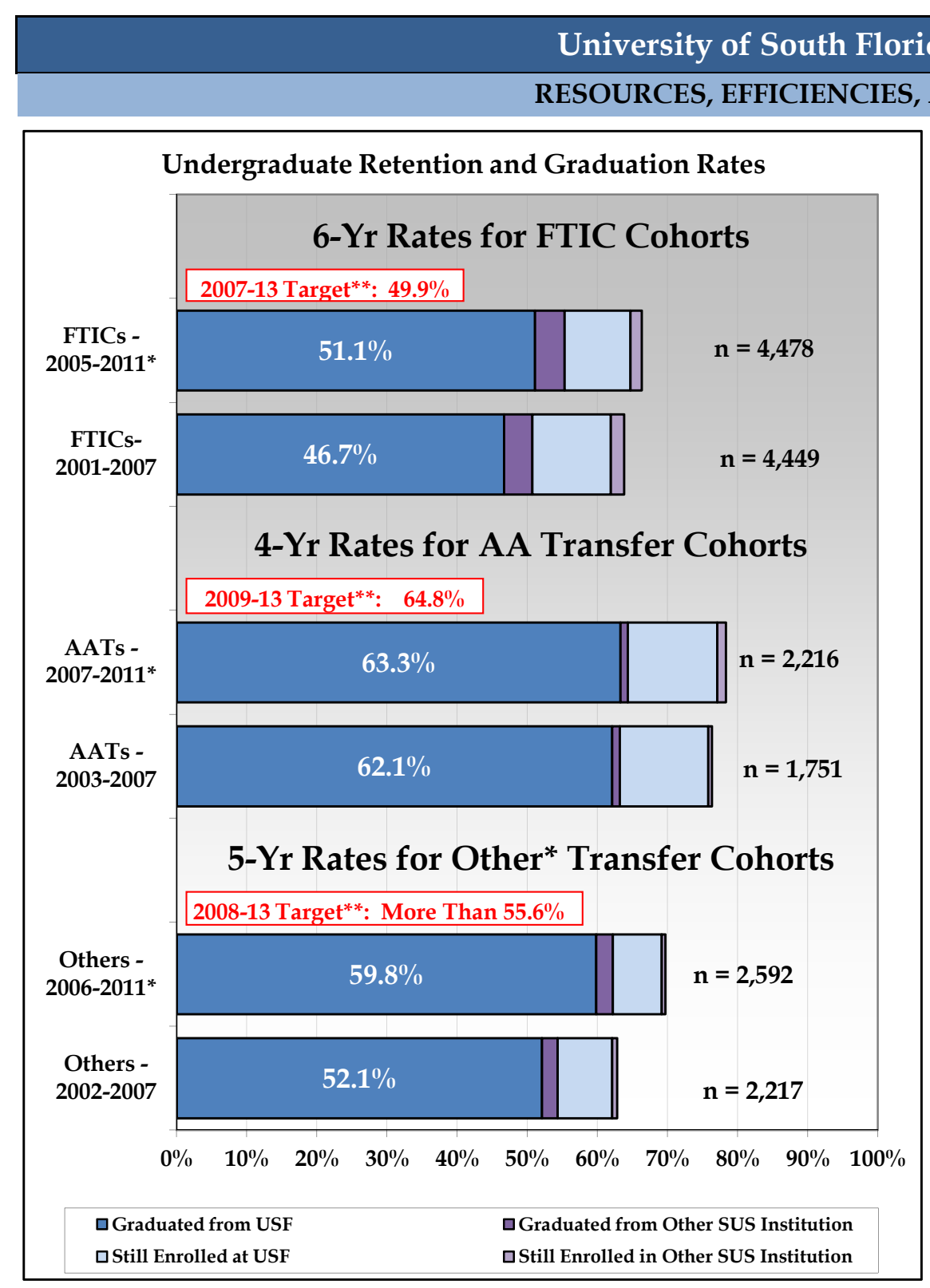

* The most recent year of data in this graph provides preliminary graduation rate data that may change with the addition of "late degrees".

**Targets Based on Graduation Rate from SAME Institution.

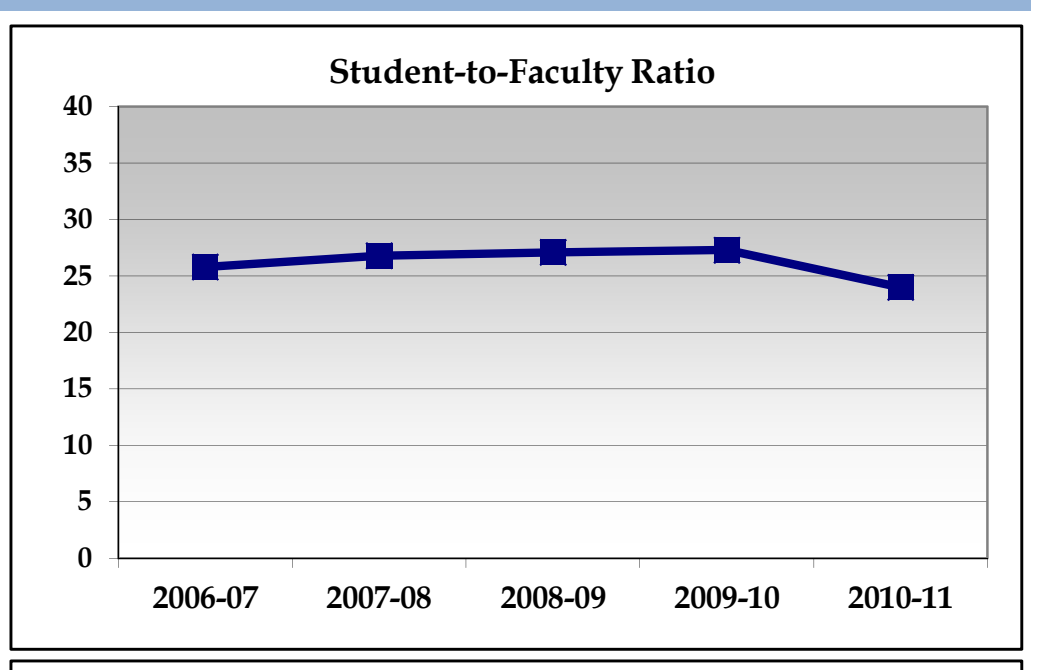

Appropriated Funding Per Actual US FTE

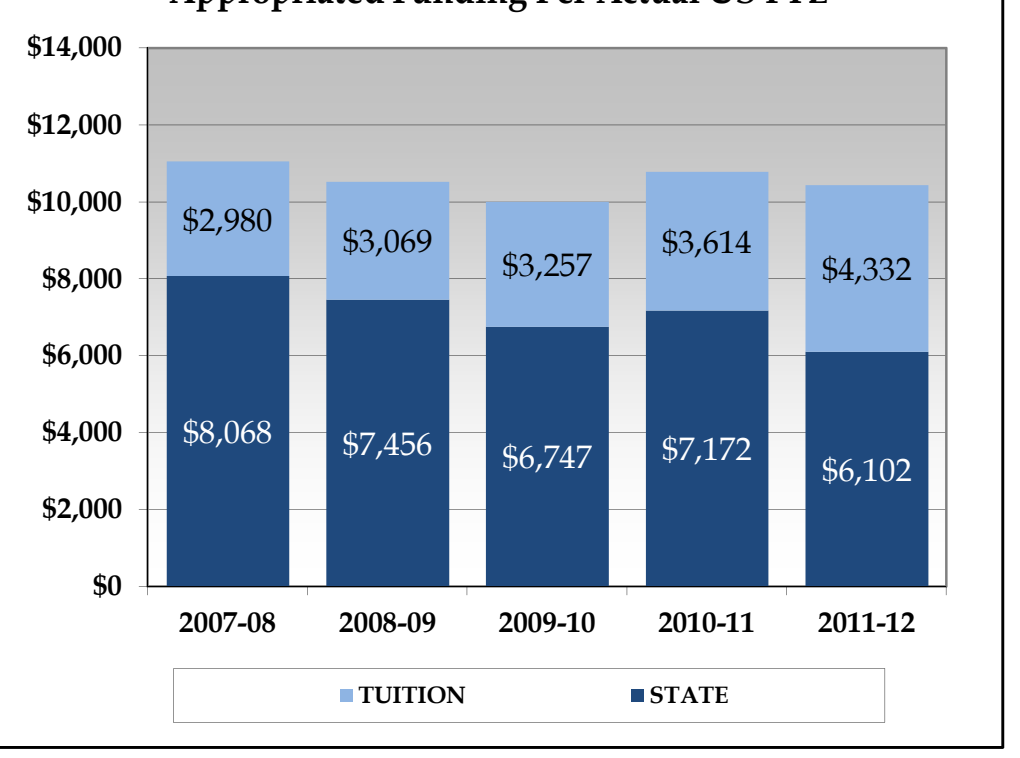

TUITION is the appropriated budget authority, not the amount actually collected. Does not include non-instructional local fees.

STATE includes General Revenues, Lottery and Other Trust funds (ie. Federal Stimulus for 2009-10 and 2010-11 only). 


\section{University of South Florida}

Key University Achievements in 2010-2011

\section{- Student awards/achievements}

1. The number of student award recipients (Goldwater, Hollings, Fulbright, and Gilman) at USF increased by $257 \%$ over last year.

2. USFSP Education graduate was selected at a Fulbright Teaching Fellow.

3. USFSM Education major received a Florida Commission on the Status of Women Achievement Award.

\section{Faculty awards/achievements}

1. Thompson's ISI citation impact of USF is 6.14 (higher than many AAU institutions); in Florida only the University of Miami exceeds this.

2. Dr Ray Arsenault's (USFSP) recent book Freedom Riders was produced by PBS as part of the American Experience series and received 3 Emmy awards.

3. USF and USFSP faculty received NSF Career Awards, AAAS and NEH Fellowships.

\section{- Program awards/achievements}

1. USF has several colleges and programs ranked in the Top 50 nationally by NRC, Chronicle of Higher Education, and US News \& World Report.

2. USFSP's College of Business ranked 36 in the Aspen Institute's Beyond Gray Pinstripes Global 100.

3. USFSM College of Education sponsored the 2011 regional Annual Children's Literature Symposium.
Research awards/achievements

1. An article by USFSM professors in the Journal of Intergenerational Relationships was cited more than any other in the Journal (202 times).

2. USF ranked $34^{\text {th }}$ in federal research expenditures (FY 2009) for public universities; $5^{\text {th }}$ fastest growing research university nationally; highest per faculty research expenditures $(\$ 242,000)$ of any Florida institution; $9^{\text {th }}$ among 300 US organizations that earned the most patents in 2010.

3. USFSP external research/sponsored program funding increased by $116.8 \%$ to $\$ 5,912,785$ - highest in the institution's history.

\section{- Institutional awards/achievements}

1. USFSM was granted accreditation by the SACS Commission on Colleges.

2. USFSP was awarded the Carnegie elective classification as a "Civically Engaged University."

3. USF ranked $8^{\text {th }}$ nationwide among 4,000 institutions on commitment to veterans' success and $110^{\text {th }}$ globally on Research Performance Index of High Impact Universities. 


\section{University of South Florida System 2010-11 Narrative Report}

\section{INTRODUCTION}

\section{Mission}

The University of South Florida System, which includes USF Tampa (USF), USF St. Petersburg (USFSP), USF SarasotaManatee (USFSM), and USF Polytechnic (USFP), catalyzes and coordinates initiatives at and among its interdependent institutions that develop graduates for 21st century careers; advance research, scholarship, and creative endeavors to improve the quality of life; and engage its communities for mutual benefit.

\section{Context}

All four institutions of the USF System (USF, USFSP, USFSM, USFP) have distinct missions and each has its own strategic plan. The USF System was formed to bring these four institutions together, so that collectively and collaboratively they could serve the region and beyond in optimal ways. The USF System seeks to find and capitalize on synergies and economies of scale among its institutions that are of benefit to students, faculty, staff, alumni, and communities. All four institutions have separate IPEDS reporting. USF, USFSP and USFSM are each accredited by SACS. By Carnegie classification, USF is a doctoral university with very high research activity and USFSP, USFSM and USFP are each classified as masters, medium level.

The members of the USF System together provide enhanced access and greater choice for students; broader advocacy; efficiencies, both academic and economic; commitment to meeting local needs; and a unified brand.
A summary report for the USF System follows. Individual institutional responses are found within the respective Annual Reports for USF, USFSM, USFSP and USFP (attached).

\section{BOARD OF GOVERNORS - STATE UNIVERSITY SYSTEM GOAL 1: ACCESS TO AND PRODUCTION OF DEGREES}

The USF System continues to provide access to an array of student experiences and a broad selection of degree programs. Collaborative degree programs, hosted programs, interdisciplinary initiatives, and undergraduate and graduate research opportunities leverage the resources of the System to increase opportunities and foster student success. Activities focus on the recruitment and retention of top-level students and highly qualified faculty to enhance learning effectiveness and degree production, improve student retention, and raise graduation rates.

The USF System serves more than 47,000 students, offering 236 degree programs: 92 bachelor's, 99 master's, 2 EdS, 39 research doctorates, and four professional doctorates. In 201011, the USF System awarded 11,211 degrees: Bachelor's 8,263; Master's 2,544; Specialist 16; Research Doctoral 267; Professional Doctoral 121.

The USF System continues to shift undergraduate enrollment to its regional campuses to expand access. Overall enrollments at the regional institutions were steady in 2010 in comparison with the previous year, with 4,350 students at USFSP, 1,913 at USFSM and 1,322 at USFP. Even with increased admission standards for transfer students, the USF 
System remains one of the nation's top destinations for these students. Within the SUS, the USF System enrolls the most students transferring from the state's public community colleges, demonstrating its commitment to supporting Florida's ' $2+2$ ' system and the needs of transfer students.

A commitment to student access and socio-economic diversity is evident in the amount of financial resources dedicated to student support. The USF System awarded to students $\$ 61.5$ million in scholarships, $\$ 82.9$ million in grants, \$37.1 million in waivers, and provided \$227.7 million in student loans. Work study made up for another \$2.2 million.

Overall, more than 35 percent of the USF System student body is comprised of students who identify themselves as non-White. Forty percent of baccalaureate degrees awarded at USF $(2,679)$ in 2009-10 went to Pell grant recipients. In 2009-10, USF far exceeded its peers in number of degrees awarded to Hispanic (830) and Non-Hispanic Black (795) students. USF is also committed to serving veterans and has worked on enhancing veterans' reintroduction. USF is and ranked $8^{\text {th }}$ among 4,000 institutions nationwide for its commitment to student veterans' success, according to the Military Times EDGE magazine, "Best for Vets" rankings.

The past year saw a $21 \%$ increase in degree production at USFSM, where the number of degree programs was reduced in 2009-10 in preparation for separate SACS accreditation. USFSM increased selected lower division offerings to facilitate access to its expanding array of baccalaureate programs. USFSM also saw a significant increase in Hispanic enrollment to $10.5 \%$
USFP implemented several strategies to improve student retention and degree production including the addition of student life and mentoring programs. Master's degree production at USFP decreased about 18\%, largely due to declining interest in Education programs, which was also observed at USFSP.

Graduate and professional education in the USF System as a whole has been on a strong forward trajectory. At USF Tampa, the only doctoral degree granting institution, impressive trends continue to be seen with regard to the number of degrees awarded, a measure of USF's commitment to graduate education and the creation of new knowledge through research, scholarship, and creative activity. This prepares the nation's next generation of leaders, thinkers, and scientists by replenishing the ranks of the professoriate for American higher education.

\section{BOARD OF GOVERNORS - STATE UNIVERSITY SYSTEM GOAL 2: MEETING STATEWIDE}

PROFESSIONAL AND WORKFORCE NEEDS

A stated goal of the USF System is to coordinate activities and promote synergies among its member institutions to create a major economic engine for the region and the state. It accomplishes this goal by challenging its institutions to increase the production of talented graduates in targeted, high demand fields; increase basic and applied research supported by the private sector; and incubate a significant number of new companies. It facilitates development of patents and licensing revenues and medical breakthroughs that enhance the quality of life throughout the region. 
The USF System offers an array of undergraduate and graduate degree programs preparing students to become leaders in business, industry, service, and research. Many degree programs align with state goals to meet professional and workforce needs, including education, health professions, the sciences, and emerging technologies.

USF continues to make rapid progress in the STEM fields, increasing the number of baccalaureate degrees by over $40 \%$ since 2004-05. In 2009-10, USF awarded more STEM baccalaureate $(1,472)$ and health baccalaureate (432) degrees than all but two of its peer institutions; in health graduate degrees awarded, USF exceeded four of its peers. In nursing and medicine, licensure and exam pass rates far exceed $90 \%$.

Regional institutions of the USF System pay particular attention to the needs of employers in their service areas. USFSM has developed degree programs in Information Technology and Criminology in response to local economic development needs, and a specially designed, online second bachelor's degree in Communication Sciences and Disorders was specifically developed to address the statewide shortage of speech-language pathologists. USFSM and USFSP have formed a partnership to address the collective needs of their local school districts, with USFSM focusing on secondary and USFSP on elementary education; USFSP recently revised and refined its Education offerings in response to the need of local school districts for elementary school teachers who are qualified to teach every child, including those with exceptional needs and those whose first language is not English. New degree programs in Entrepreneurship, Health Sciences, Biology, and Digital Journalism address regional workforce needs in STEM-related areas.

\section{BOARD OF GOVERNORS - STATE UNIVERSITY SYSTEM GOAL 3: BUILDING WORLD-CLASS ACADEMIC PROGRAMS AND RESEARCH CAPACITY}

The USF System continues to make advances in research and innovation with total research expenditures exceeding \$371 million and federal expenditures exceeding \$213 million. Over $98 \%$ of funding is generated by USF, where the mean funding per faculty member is $\$ 242,000$, the highest for all Florida institutions. Federal research expenditures have increased 252\% between 1999 and 2010, which places USF as the nation's $5^{\text {th }}$ fastest growing research university.

USF has several first-class academic programs as measured by faculty performance. It is ranked $110^{\text {th }}$ globally on the Research Performance Index calculated by the High Impact Universities. This places USF second in Florida and above all but two of its peers. In another significant measure of academic quality, Thompson's ISI metric shows that the fiveyear citation impact of USF is 6.14; this figure lags only the University of Miami in the state and exceeds that of many AAU institutions and its peers.

USF units ranked nationally include: the College of Business recognized nationally as $14^{\text {th }}$ best business school (MISQ/ISR), and also $31^{\text {st }}$ globally for research contributions (UTD); the graduate Entrepreneurship program ranked 19th in the nation, as reported by Princeton Review and Entrepreneurship Magazine; the College of Education ranked 21st in the nation among graduate colleges of Education in generating external funding; four graduate programs ranked in the top 50 in US World \& News: Criminology (22nd), Audiology (24th), Rehabilitation \& Mental Health Counseling (30th), and Speech 
Language Pathology $\left(46^{\text {th }}\right)$, and three doctoral programs ranked in the top 10 by the Chronicle of Higher Education: Criminology, Communication Sciences \& Disorders, and Aging Studies.

At USFP, a plan was developed to align degree programs with STEM, STEM-related Professions, and Liberal Arts fields in aspirational peer institutions. The Division of Innovation Management developed and implemented a mentoring component for the MBA Program and developed the program proposal for an interdisciplinary degree in Accounting and Financial Management. A joint, NSF-funded project with Polk State College (PSC) will produce advanced Linux systems administrators through a novel, dual-track articulated online curriculum leading to the MS in Information Technology.

USFSP's College of Business was the only Florida entity included $\left(36^{\text {th }}\right)$ in the Global 100 ranking of the Aspen Institute's "Beyond Gray Pinstripes" based on the strength of an institution's programs in corporate and social responsibility; and its College of Education, in partnership with SRI International and the Pinellas County School District, has implemented a nationally recognized program for teaching algebra and geometry in middle school using digital technology that received funding in 2011 from the Next Generation Learning Challenges program (Gates Foundation, Hewlett Foundation, Educause).

BOARD OF GOVERNORS - STATE UNIVERSITY SYSTEM GOAL 4: MEETING COMMUNITY NEEDS AND FULFILLING UNIQUE INSTITUTIONAL RESPONSIBILITIES
The USF System's mission statement includes a commitment to community engagement by facilitating increased collaborations among its member institutions and across the region.

The challenge for USF, the main research campus in Tampa, is to meet community needs while fulfilling its unique mission as a pre-eminent research university with state, national and global impact, and positioned for membership in the Association of American Universities (AAU). Locally, USF meets the needs of a diverse metropolitan population while also serving students from across the USA and the world. USF has seen increases in its global activities, international faculty exchanges, recruitment of fee-paying international students and student study abroad programs, thus securing Florida's place in the global economy and enhancing employment opportunities.

USF is meeting the special challenges of serving a diverse population of students, including ethnic and socio-economic diversity. Its enrollment includes a large percentage of Hispanic (17\%) and Non-Hispanic Black (12\%) as well Asian $(6 \%)$ students. In addition, over $30 \%$ of the undergraduate students are PELL eligible, many of whom are the first in their families to attend college. USF is also committed to serving veterans and enhancing veterans' reintroduction and is ranked $8^{\text {th }}$ among 4,000 institutions nationwide for its commitment to veteran students' success, according to the Military Times EDGE magazine, "Best for Vets" rankings.

USF and USFSP are among about 300 institutions nationally to be awarded the Carnegie Community Engaged classification. USFSP has developed partnerships in its local community through its Lead-Learn Serve (LLS) program that is funded by 
a $\$ 400,000$ grant from the Corporation for National and Community Service. USFSP is also host to Project STINGRAY, a statewide model program funded by the Florida Department of Education to increase access to higher education for persons with intellectual disabilities.

USFP has established community outreach centers that provide economic development and entrepreneurship information sessions for local businesses and opportunities for middle and high school students to learn about USFP and receive general college mentoring. USFP's Extended University has developed international partnership agreements with educational institutions and government agencies in Europe, Asia and Latin America, and the Division of Education has launched a comprehensive program of STEM initiatives in Pre-K through 12 schools through TIES, the Teacher Institute for Excellence in STEM.

At USFSM, several recent efforts are evidence of a commitment to meeting community needs. In partnership with local government and a private foundation, USFSM opened the new USFSM@North Port instructional site serving south Sarasota county students. USFSM received a one-year, $\$ 247,500$ grant from the Health Resources and Services Administration (HRSA) to develop a five-year strategic plan for delivery of health care degrees/certificates that meet workforce needs in Sarasota and Manatee Counties. In partnership with the Community Foundation of Sarasota County, USFSM offered a ten-week certificate course for 22 potential and current nonprofit managers and leaders to prepare them for the unique challenges of today's nonprofit climate.
PROGRESS ON PRIMARY INSTITUTIONAL GOALS AND METRICS AS OUTLINED IN THE UNIVERSITY WORK PLAN

\section{Goal 1: Improve baccalaureate retention and graduation}

The USF System has adopted a comprehensive approach to promoting student success, focusing on preparedness, affordability, and student support services, for example:

- Implementing a new degree audit system (DegreeWorks) to promote timely progression.

- Raising admission standards to improve readiness.

- Developing a financial aid leveraging model to support enrollment objectives and maintain access and affordability.

- Improving teaching and learning outcomes through course redesign in high enrollment classes with low passing rates.

- Admission referrals from USF to USFSP

- Increasing the number of faculty and academic advisors.

- Improving orientation and expanding tutoring and career services.

- Promoting undergraduate research.

\section{Goal 2: Revenue enhancement and public- private partnerships}

The USF System continues to expand and diversify its resource base to maintain financial sustainability to meet its distinctive mission. Public-private partnerships of the USF System institutions include ties with Draper Laboratory, SRI International, the Mote Marine Research Institute, and All Children's Hospital. USF is host to the Florida Institute of Oceanography, and is an active partner in the Florida Energy Systems Consortium (FESC). According to the Intellectual 
Property Owners Association, USF now ranks $9^{\text {th }}$ world-wide of 14 universities among 300 organizations that carried the most patents in 2010.

\section{Goal 3: Global initiatives}

USF has seen increases in international faculty exchanges, recruitment of fee-paying international students and student study abroad programs, adding greatly to Florida's place in the global economy and employment opportunities. USF was selected by the Association of American Colleges and Universities as one of 32 universities to participate in General Education for a Global Century, a curriculum and faculty development project aimed at educating students in all aspects of a rapidly globalizing society. USFSP developed an undergraduate degree in Global Business, and USFP has established multiple international partnerships.

\section{Goal 4: Technological and innovative advances - marine and coastal environments - health}

Marine Science and Coastal Technologies represents a key focus area, as demonstrated by the rapid response to the Gulf Oil spill of 2010 that involved faculty from across the USF System. Technological advances have been further enhanced through innovative USF Health initiatives such as the Center for Advanced Medical Learning and Simulation. The USF System is uniquely positioned to serve as the intellectual hub for technological advances and workforce development across the Tampa Bay region.

\section{Goal 5: Community engagement}

All USF System institutions are committed to facilitate and promote community engagement, social enterprise, and global collaborations in education, research and service learning. Recognition of the USF System's success is the classification of two of its institutions, USF and USFSP, by the Carnegie Foundation as Community Engaged.

\section{ADDITIONAL INFORMATION ON QUALITY,}

\section{RESOURCES, EFFICIENCIES, AND EFFECTIVENESS}

The USF System continues to focus on initiatives that result in improvements and/or cost savings for re-investment, including implementation of a System-Wide Services model to leverage economies of scale in a variety of operational areas.

Costs are allocated annually across the institutions of the USF System.

USF is one of a small number of universities nationwide to receive a GOLD RATING for building an environmentallyconscious campus, according to the Association for the Advancement of Sustainability in Higher Education (2011).

USFP has saved approximately $\$ 300,000$ in telecommunication costs over the past 5 years with the implementation of a high function, integrated phone system and has created additional recurring savings by moving toward convergent networks integrating operational systems into the infrastructure of the network, removing the necessity to have separate cabling and additional equipment for each service.

At USFSM, in addition to reducing the campus' electrical KWH demand by $21 \%$ since $2006-07$, the Facilities Planning \& Management division received grants in 2011 to install a 
campus emergency mass notification system and thermal storage for its central energy plant.

USFSP has reorganized its administrative functions to increase efficiency and deliver outstanding student services with reduced resources. It has also continued to reduce its energy consumption and now consumes $11 \%$ less energy than in 2007, which has saved nearly \$175,000 annually. Finally, environmentally friendly practices such as greatly reduced paper consumption, and conversion to eco-friendly cleaning products and maintenance have resulted in more effective operations consistent with USFSP's strategic goal of environmental stewardship.

\section{ADDITIONAL RESOURCES}

USF System Strategic Plan 2010-2015

http://system.usf.edu/pdfs/USF_System_Strategic_Plan.pdf

USF System Annual Reports and Work Plans

http://www.ods.usf.edu/Plans/Strategic/SUS-annual-

report-workplans.htm

USF System Cost Model http://system.usf.edu/costmodel.asp 


\section{Section 1 - Financial Resources}

\begin{tabular}{|c|c|c|c|c|c|}
\hline & $\begin{array}{r}2007-08 \\
\text { Actual }\end{array}$ & $\begin{array}{r}2008-09 \\
\text { Actual }\end{array}$ & $\begin{array}{r}2009-10 \\
\text { Actual }\end{array}$ & $\begin{array}{r}2010-11 \\
\text { Actual } \\
\end{array}$ & $\begin{array}{c}2011-12 \\
\text { Estimates }\end{array}$ \\
\hline $\begin{array}{l}\text { Recurring } \\
\text { State Funds } \\
\text { (GR \& Lottery) }\end{array}$ & $\$ 291,560,395$ & $\$ 269,447,277$ & $\$ 241,841,349$ & $\$ 262,674,613$ & $\$ 239,238,035$ \\
\hline $\begin{array}{l}\text { Non-Recurring } \\
\text { State Funds } \\
\text { (GR \& Lottery) }\end{array}$ & $\$ 8,671,511$ & $\$ 11,937,078$ & $\$ 1,585,518$ & $\$ 3,873,018$ & $\$ 2,656,583$ \\
\hline $\begin{array}{l}\text { Tuition } \\
\text { (Resident \& Non-Resident) }\end{array}$ & $\$ 109,722,907$ & $\$ 112,352,760$ & $\$ 118,853,735$ & $\$ 129,324,373$ & $\$ 152,030,825$ \\
\hline Tuition Differential Fee & $\$ 0$ & $\$ 2,626,024$ & $\$ 7,458,495$ & $\$ 14,376,755$ & $\$ 20,996,275$ \\
\hline $\begin{array}{l}\text { Other Revenues } \\
\text { (Includes Misc. Fees \& Fines) }\end{array}$ & $\$ 3,870,454$ & $\$ 3,862,283$ & $\$ 3,802,375$ & $\$ 3,364,814$ & $\$ 3,936,506$ \\
\hline $\begin{array}{l}\text { Phosphate Research } \\
\text { Trust Fund }\end{array}$ & $\$ 7,268,856$ & $\$ 7,287,963$ & $\$ 7,304,874$ & $\$ 7,330,654$ & $\$ 7,334,170$ \\
\hline Federal Stimulus Funds & $\$ 0$ & $\$ 0$ & $\$ 18,790,945$ & $\$ 17,980,176$ & $\$ 0$ \\
\hline TOTAL & $\$ 421,094,123$ & $\$ 407,513,385$ & $\$ 399,637,291$ & $\$ 438,924,403$ & $\$ 426,192,394$ \\
\hline
\end{tabular}

\section{TABLE 1B. University Education and General Expenditures}

\begin{tabular}{|c|c|c|c|c|c|}
\hline & $\begin{array}{c}2007-08 \\
\text { Actual }\end{array}$ & $\begin{array}{c}2008-09 \\
\text { Actual }\end{array}$ & $\begin{array}{r}\text { 2009-10 } \\
\text { Actual }\end{array}$ & $\begin{array}{r}\text { 2010-11 } \\
\text { Actual }\end{array}$ & $\begin{array}{c}2011-12 \\
\text { Estimates }\end{array}$ \\
\hline Instruction/Research & $\$ 254,025,777$ & $\$ 232,420,538$ & $\$ 248,178,440$ & $\$ 264,299,730$ & $\$ 307,810,244$ \\
\hline $\begin{array}{l}\text { Institutes and Research } \\
\text { Centers }\end{array}$ & $\$ 1,193,342$ & $\$ 1,024,089$ & $\$ 968,072$ & $\$ 721,815$ & $\$ 862,820$ \\
\hline PO\&M & $\$ 38,802,332$ & $\$ 36,124,122$ & $\$ 35,302,128$ & $\$ 34,678,763$ & $\$ 41,013,185$ \\
\hline $\begin{array}{l}\text { Administration and } \\
\text { Support Services }\end{array}$ & $\$ 21,181,757$ & $\$ 28,501,983$ & $\$ 23,730,020$ & $\$ 26,484,388$ & $\$ 40,547,756$ \\
\hline Radio/TV & $\$ 861,949$ & $\$ 815,056$ & $\$ 892,243$ & $\$ 890,441$ & $\$ 958,833$ \\
\hline Library/Audio Visual & $\$ 14,415,025$ & $\$ 14,141,123$ & $\$ 14,667,694$ & $\$ 13,622,890$ & $\$ 14,340,762$ \\
\hline Museums and Galleries & $\$ 740,454$ & $\$ 729,951$ & $\$ 640,699$ & $\$ 702,092$ & $\$ 629,272$ \\
\hline Agricultural Extension & $\$ 0$ & $\$ 0$ & $\$ 0$ & $\$ 0$ & $\$ 0$ \\
\hline Student Services & $\$ 22,958,049$ & $\$ 22,054,934$ & $\$ 21,924,396$ & $\$ 21,251,998$ & $\$ 17,976,900$ \\
\hline Intercollegiate Athletics & $\$ 513,486$ & $\$ 352,411$ & $\$ 356,212$ & $\$ 358,193$ & $\$ 384,311$ \\
\hline $\begin{array}{l}\text { Academic Infrastructure } \\
\text { Support Organization }\end{array}$ & $\$ 0$ & $\$ 0$ & $\$ 0$ & $\$ 181,684$ & $\$ 195,646$ \\
\hline TOTAL & $\$ 354,692,171$ & $\$ 336,164,207$ & $\$ 346,659,904$ & $\$ 363,191,994$ & $\$ 424,719,729$ \\
\hline
\end{tabular}

\begin{tabular}{|l|l|l|l|l|l|}
$\mathbf{\$ 3 5 4 , 6 9 2 , 1 7 1}$ & $\mathbf{\$ 3} 36,164,207$ & $\mathbf{\$ 3 4 6 , 6 5 9 , 9 0 4}$ & $\mathbf{\$ 3 6 3 , 1 9 1 , 9 9 4}$ & $\mathbf{\$ 4 2 4 , 7 1 9 , 7 2 9}$ \\
\hline
\end{tabular}

The table reports the actual and estimated amount of expenditures from revenues appropriated by the Legislature for each fiscal year. The expenditures are classified by Program Component (i.e.,

Instruction/Research, PO\&M, Administration, etc.) for activities directly related to instruction, research and public service. The table does not include expenditures classified as non-operating expenditures

(i.e., to service asset-related debts), and therefore excludes a small portion of the amount appropriated each year by the Legislature. Also, the table does not include expenditures from funds carried forward from previous years.
Section 1 - Financial Resources (continued)

\begin{tabular}{|c|c|c|c|c|c|}
\hline & $\begin{array}{c}2007-08 \\
\text { Actual }\end{array}$ & $\begin{array}{c}2008-09 \\
\text { Actual }\end{array}$ & $\begin{array}{l}\text { 2009-10 } \\
\text { Actual }\end{array}$ & $\begin{array}{c}2010-11 \\
\text { Actual }\end{array}$ & $\begin{array}{c}2011-12 \\
\text { Estimates }\end{array}$ \\
\hline \multicolumn{6}{|c|}{ Appropriated Funding per FTE } \\
\hline General Revenue per FTE & $\$ 7,276$ & $\$ 6,493$ & $\$ 5,424$ & $\$ 5,782$ & $\$ 5,097$ \\
\hline Lottery Funds per FTE & $\$ 601$ & $\$ 775$ & $\$ 670$ & $\$ 768$ & $\$ 825$ \\
\hline Tuition \& Fees per FTE & $\$ 3,064$ & $\$ 3,214$ & $\$ 3,628$ & $\$ 3,762$ & $\$ 4,239$ \\
\hline Other Trust Funds per FTE & $\$ 191$ & $\$ 188$ & $\$ 653$ & $\$ 622$ & $\$ 180$ \\
\hline Total per FTE & $\$ 11,129$ & $\$ 10,670$ & $\$ 10,375$ & $\$ 10,934$ & $\$ 10,341$ \\
\hline \multicolumn{6}{|l|}{ Actual Funding per FTE } \\
\hline Tuition \& Fees per FTE & $\$ 2,980$ & $\$ 3,069$ & $\$ 3,257$ & $\$ 3,614$ & $\$ 4,332$ \\
\hline Total per FTE & $\$ 11,048$ & $\$ 10,525$ & $\$ 10,004$ & $\$ 10,786$ & $\$ 10,434$ \\
\hline \multicolumn{6}{|c|}{$\begin{array}{l}\text { Notes: (1) FTE is based on actual FTE, not funded FTE; (2) does not include Health-Science Center } \\
\text { funds or FTE; (3) FTE for these metrics uses the standard IPEDS definition of FTE, equal to } 30 \text { credit } \\
\text { hours for undergraduates and } 24 \text { for graduates; and (4) actual funding per student is based on actual } \\
\text { tuition and E\&G fees (does not include local fees) collected. }\end{array}$} \\
\hline
\end{tabular}

\begin{tabular}{|c|c|c|c|c|c|}
\hline & $\begin{array}{r}\text { 2007-08 } \\
\text { Actual }\end{array}$ & $\begin{array}{r}2008-09 \\
\text { Actual }\end{array}$ & $\begin{array}{r}2009-10 \\
\text { Actual }\end{array}$ & $\begin{array}{c}\text { 2010-11 } \\
\text { Actual }\end{array}$ & $\begin{array}{c}2011-12 \\
\text { Estimates }\end{array}$ \\
\hline \multicolumn{6}{|c|}{ Auxiliary Enterprises } \\
\hline Revenues & $\$ 163,094,763$ & $\$ 171,361,009$ & $\$ 142,802,349$ & $\$ 159,279,590$ & $\$ 157,500,922$ \\
\hline Expenditures & $\$ 150,015,206$ & $\$ 240,123,445$ & $\$ 115,485,207$ & $\$ 128,022,768$ & $\$ 150,967,068$ \\
\hline \multicolumn{6}{|c|}{ Contracts \& Grants } \\
\hline Revenues & $\$ 260,378,731$ & $\$ 346,300,000$ & $\$ 296,910,481$ & $\$ 280,658,090$ & $\$ 375,000,000$ \\
\hline Expenditures & $\$ 293,512,444$ & $\$ 340,000,000$ & $\$ 300,467,449$ & $\$ 305,640,232$ & $\$ 380,000,000$ \\
\hline \multicolumn{6}{|l|}{ Local Funds } \\
\hline Revenues & $\$ 145,745,675$ & $\$ 135,058,791$ & $\$ 408,521,266$ & $\$ 442,397,152$ & $\$ 436,228,767$ \\
\hline Expenditures & $\$ 133,879,634$ & $\$ 153,572,417$ & $\$ 406,432,437$ & $\$ 440,842,216$ & $\$ 439,073,527$ \\
\hline
\end{tabular}

\begin{tabular}{|c|c|c|c|c|c|}
\hline & $\begin{array}{c}\text { 2007-08 } \\
\text { Actual }\end{array}$ & $\begin{array}{c}\text { 2008-09 } \\
\text { Actual }\end{array}$ & $\begin{array}{c}\text { 2009-10 } \\
\text { Actual }\end{array}$ & $\begin{array}{c}\text { 2010-11 } \\
\text { Actual }\end{array}$ & $\begin{array}{c}\text { 2011-12 } \\
\text { Estimates }\end{array}$ \\
\hline $\begin{array}{c}\text { Total } \\
\text { Revenues }\end{array}$ & $\$ 990,313,292$ & $\$ 1,060,233,185$ & $\$ 1,247,871,387$ & $\$ 1,321,259,235$ & $\$ 1,394,922,083$ \\
\hline $\begin{array}{c}\text { Total } \\
\text { Expenditures }\end{array}$ & $\$ 932,099,455$ & $\$ 1,069,860,069$ & $\$ 1,169,044,997$ & $\$ 1,237,697,210$ & $\$ 1,394,760,324$ \\
\hline
\end{tabular}




\section{Section 1 - Financial Resources (continued)}

\section{TABLE 1F. Voluntary Support of Higher Education}

\begin{tabular}{|c|c|c|c|c|c|}
\hline & $\mathbf{2 0 0 5 - 0 6}$ & $\mathbf{2 0 0 6 - 0 7}$ & $\mathbf{2 0 0 7 - 0 8}$ & $\mathbf{2 0 0 8 - 0 9}$ & $\mathbf{2 0 0 9 - 1 0}$ \\
\hline $\begin{array}{c}\text { Endowment Market } \\
\text { Value (Thousand \$) }\end{array}$ & $\$ 329,832$ & $\$ 388,516$ & $\$ 360,035$ & $\$ 275,398$ & $\$ 295,921$ \\
\hline $\begin{array}{c}\text { Annual Gifts } \\
\text { Received (\$) }\end{array}$ & $\$ 46,346,593$ & $\$ 56,826,407$ & $\$ 44,682,695$ & $\$ 34,010,969$ & $\$ 36,385,343$ \\
\hline $\begin{array}{c}\text { Percentage of } \\
\text { Graduates Who are } \\
\text { Alumni Donors }\end{array}$ & $5.6 \%$ & $4.8 \%$ & $8.2 \%$ & $8.0 \%$ & $9.7 \%$ \\
\hline
\end{tabular}

\section{TABLE 1G. University Federal Stimulus Dollars (ARRA)}

\begin{tabular}{|l|c|c|}
\hline & $\begin{array}{c}\mathbf{2 0 0 9 - 1 0} \\
\text { Actual }\end{array}$ & $\begin{array}{c}\mathbf{2 0 1 0 - 1 1} \\
\text { Actual }\end{array}$ \\
\hline Jobs Saved/Created & $\$ 23,360,035$ & $\$ 22,331,948$ \\
\hline Scholarships & $\$ 0$ & $\$ 0$ \\
\hline Library Resources & $\$ 0$ & $\$ 0$ \\
\hline Building Repairs/Alterations & $\$ 0$ & $\$ 0$ \\
\hline Motor Vehicles & $\$ 0$ & $\$ 0$ \\
\hline Printing & $\$ 0$ & $\$ 0$ \\
\hline Furniture \& Equipment & $\$ 0$ & $\$ 0$ \\
\hline Information Technology Equipment & $\$ 0$ & $\$ 0$ \\
\hline Financial Aid to Medical Students & $\$ 0$ & $\$ 0$ \\
\hline Other & $\$ 0$ & $\$ 0$ \\
\hline TOTAL & $\mathbf{2 2 3 , 3 6 0 , 0 3 5}$ & $\mathbf{2 2 , 3 3 1 , 9 4 8}$ \\
\hline
\end{tabular}

Section 1 - Financial Resources (continued)

TABLE 1H. Health-Science Center Education and General Revenues

\begin{tabular}{|c|c|c|c|c|c|}
\hline & $\begin{array}{l}\text { 2007-08 } \\
\text { Actual }\end{array}$ & $\begin{array}{c}2008-09 \\
\text { Actual }\end{array}$ & $\begin{array}{c}\text { 2009-10 } \\
\text { Actual }\end{array}$ & $\begin{array}{c}\text { 2010-11 } \\
\text { Actual }\end{array}$ & $\begin{array}{c}2011-12 \\
\text { Estimates }\end{array}$ \\
\hline $\begin{array}{l}\text { Recurring } \\
\text { State Funds } \\
\text { (GR \& Lottery) }\end{array}$ & $\$ 65,814,423$ & $\$ 62,041,950$ & $\$ 61,549,150$ & $\$ 61,824,195$ & $\$ 63,107,673$ \\
\hline $\begin{array}{l}\text { Non-Recurring } \\
\text { State Funds } \\
\text { (GR \& Lottery) }\end{array}$ & $\$ 1,626,101$ & $\$ 635,338$ & $\$ 0$ & $\$ 1,175,000$ & $\$ 250,000$ \\
\hline $\begin{array}{l}\text { Tuition } \\
\text { (Resident \& Non-Resident) }\end{array}$ & $\$ 22,648,230$ & $\$ 26,347,362$ & $\$ 29,988,216$ & $\$ 32,942,009$ & $\$ 34,571,985$ \\
\hline Tuition Differential Fee & $\$ 0$ & $\$ 111,799$ & $\$ 501,511$ & $\$ 947,321$ & $\$ 1,399,644$ \\
\hline $\begin{array}{l}\text { Other Revenues } \\
\text { (Includes Misc. Fees \& Fines) }\end{array}$ & $\$ 0$ & $\$ 0$ & $\$ 1,331$ & $\$ 1,280$ & $\$ 0$ \\
\hline $\begin{array}{l}\text { Other Operating } \\
\text { Trust Funds }\end{array}$ & $\$ 0$ & $\$ 0$ & $\$ 0$ & $\$ 0$ & $\$ 0$ \\
\hline Federal Stimulus Funds & $\$ 0$ & $\$ 0$ & $\$ 4,569,090$ & $\$ 4,351,772$ & $\$ 0$ \\
\hline TOTAL & $\$ 89,392,454$ & $\$ 89,136,449$ & $\$ 96,609,298$ & $\$ 101,241,577$ & $\$ 99,329,302$ \\
\hline
\end{tabular}

TABLE 1I. Health-Science Center Education and General Expenditures

\begin{tabular}{|c|c|c|c|c|c|}
\hline & $\begin{array}{l}\text { 2007-08 } \\
\text { Actual }\end{array}$ & $\begin{array}{l}\text { 2008-09 } \\
\text { Actual }\end{array}$ & $\begin{array}{l}2009-10 \\
\text { Actual }\end{array}$ & $\begin{array}{r}\text { 2010-11 } \\
\text { Actual }\end{array}$ & $\begin{array}{l}2011-12 \\
\text { Estimates }\end{array}$ \\
\hline Instruction/Research & $\$ 64,625,114$ & $\$ 64,047,565$ & $\$ 68,082,738$ & $\$ 76,521,544$ & $\$ 96,596,669$ \\
\hline $\begin{array}{l}\text { Institutes and Research } \\
\text { Centers }\end{array}$ & $\$ 154,396$ & $\$ 1,153$ & $\$ 0$ & $\$ 1,640$ & $\$ 0$ \\
\hline PO\&M & $\$ 64,095$ & $\$ 262,695$ & $\$ 84,684$ & $\$ 1,373,059$ & $\$ 1,993,076$ \\
\hline $\begin{array}{l}\text { Administration and } \\
\text { Support Services }\end{array}$ & $\$ 5,200,070$ & $\$ 4,463,186$ & $\$ 5,033,768$ & $\$ 6,375,343$ & $\$ 6,581,526$ \\
\hline Radio/TV & $\$ 0$ & $\$ 0$ & $\$ 0$ & $\$ 0$ & $\$ 0$ \\
\hline Library/Audio Visual & $\$ 2,903,725$ & $\$ 2,787,282$ & $\$ 2,473,154$ & $\$ 2,437,820$ & $\$ 2,289,811$ \\
\hline Museums and Galleries & $\$ 0$ & $\$ 0$ & $\$ 0$ & $\$ 0$ & $\$ 0$ \\
\hline Agricultural Extension & $\$ 0$ & $\$ 0$ & $\$ 0$ & $\$ 0$ & $\$ 0$ \\
\hline $\begin{array}{l}\text { Teaching Hospital \& } \\
\text { Allied Clinics }\end{array}$ & $\$ 0$ & $\$ 0$ & $\$ 0$ & $\$ 0$ & $\$ 0$ \\
\hline Student Services & $\$ 0$ & $\$ 0$ & $\$ 0$ & $\$ 0$ & $\$ 0$ \\
\hline Intercollegiate Athletics & $\$ 0$ & $\$ 0$ & $\$ 0$ & $\$ 0$ & $\$ 0$ \\
\hline
\end{tabular}

Intercollegiate Athletics

\begin{tabular}{|l|r|r|r|r|r|} 
& & & \\
$\mathbf{\$ 7 2 , 9 4 7 , 4 0 0}$ & $\mathbf{\$ 7 1 , 5 6 1 , 8 8 1}$ & $\mathbf{\$ 7 5 , 6 7 4 , 3 4 4}$ & $\mathbf{\$ 8 6 , 7 0 9 , 4 0 6}$ & $\mathbf{\$ 1 0 7 , 4 6 1 , 0 8 2}$ \\
\hline
\end{tabular}

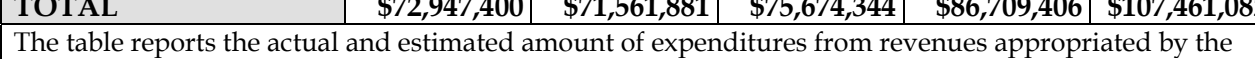
Legislature for each fiscal year. The expenditures are classified by Program Component (i.e.,

Instruction/Research, PO\&M, Administration, etc.) for activities directly related to instruction, research and public service. The table does not include expenditures classified as non-operating expenditures

(i.e., to service asset-related debts), and therefore excludes a small portion of the amount appropriated each year by the Legislature. Also, the table does not include expenditures from funds carried forward from previous years. 


\section{Section 1 - Financial Resources (continued)}

TABLE 1J. Health-Science Center Faculty Practice Plans

\begin{tabular}{|c|c|c|c|c|c|}
\hline & $\begin{array}{c}2007-08 \\
\text { Actual }\end{array}$ & $\begin{array}{r}2008-09 \\
\text { Actual }\end{array}$ & $\begin{array}{r}2009-10 \\
\text { Actual }\end{array}$ & $\begin{array}{c}2010-11 \\
\text { Actual }\end{array}$ & $\begin{array}{c}2011-12 \\
\text { Estimates }\end{array}$ \\
\hline \multicolumn{6}{|c|}{ Faculty Practice Plans } \\
\hline Revenues & $\$ 174,916,000$ & $\$ 150,206,988$ & $\$ 174,727,927$ & $\$ 183,622,430$ & $\$ 185,396,848$ \\
\hline Expenditures & $\$ 172,944,428$ & $\$ 156,641,074$ & $\$ 173,643,913$ & $\$ 182,116,435$ & $\$ 184,396,850$ \\
\hline \multicolumn{6}{|c|}{$\begin{array}{l}\text { Notes: Faculty practice plan revenue is generated from the delivery of patient care services provided } \\
\text { by the faculty whose clinical activities are not supported by state or other funds. The collection of these } \\
\text { revenues is vital to pay all the costs associated with the delivery of the patient care services, and are not } \\
\text { available to support the education or research missions of the medical school. }\end{array}$} \\
\hline
\end{tabular}

\section{Section 2 - Personnel}

\begin{tabular}{|c|c|c|c|c|c|c|c|c|c|c|}
\hline \multicolumn{1}{|c|}{ TABLE 2A. Personnel Headcount } \\
\hline & $\begin{array}{c}\text { Full } \\
\text { Time }\end{array}$ & $\begin{array}{c}\text { Part- } \\
\text { Time }\end{array}$ & $\begin{array}{c}\text { Full- } \\
\text { Time }\end{array}$ & $\begin{array}{c}\text { Part- } \\
\text { Time }\end{array}$ & $\begin{array}{c}\text { Full- } \\
\text { Time }\end{array}$ & $\begin{array}{c}\text { Part- } \\
\text { Time }\end{array}$ & $\begin{array}{c}\text { Full- } \\
\text { Time }\end{array}$ & $\begin{array}{c}\text { Part- } \\
\text { Time }\end{array}$ & $\begin{array}{c}\text { Full- } \\
\text { Time }\end{array}$ & $\begin{array}{c}\text { Part- } \\
\text { Time }\end{array}$ \\
\hline $\begin{array}{c}\text { Total Tenure/ } \\
\text { Tenure-track } \\
\text { Faculty }\end{array}$ & 1,210 & 77 & 1,175 & 78 & 1,103 & 80 & 1,115 & 79 & 1,142 & 79 \\
\hline $\begin{array}{c}\text { Total Non- } \\
\text { Tenure Track } \\
\text { Faculty }\end{array}$ & 543 & 165 & 582 & 170 & 476 & 154 & 503 & 241 & 523 & 397 \\
\hline $\begin{array}{c}\text { Instructors } \\
\text { Without Faculty } \\
\text { Status }\end{array}$ & 0 & 0 & 0 & 0 & 0 & 0 & 0 & 0 & 0 & 3 \\
\hline $\begin{array}{c}\text { Total Graduate } \\
\text { Assistants/ } \\
\text { Associates }\end{array}$ & 0 & 1,752 & 0 & 1,725 & 0 & 1,774 & 0 & 1,866 & 0 & 2,071 \\
\hline $\begin{array}{c}\text { Total Executive/ } \\
\text { Administrative/ } \\
\text { Managerial }\end{array}$ & 528 & 16 & 603 & 19 & 606 & 15 & 634 & 17 & 686 & 16 \\
\hline $\begin{array}{c}\text { Total Other } \\
\text { Professional }\end{array}$ & 1,829 & 101 & 1,715 & 93 & 1,710 & 72 & 1,735 & 130 & 1,809 & 132 \\
\hline $\begin{array}{c}\text { Total Non- } \\
\text { Professional }\end{array}$ & 1,686 & 31 & 1,792 & 41 & 1,731 & 40 & 1,721 & 245 & 1,789 & 286 \\
\hline $\begin{array}{c}\text { TOTAL } \\
\text { Totall }\end{array}$ & $\mathbf{7 , 9 3 8}$ & $\mathbf{7 , 9 9 3}$ & $\mathbf{7 , 7 6 1}$ & $\mathbf{8 , 2 8 6}$ & $\mathbf{8 , 9 3 3}$ \\
\hline
\end{tabular}




\section{Section 3 - Enrollment}

TABLE 3A. University Full-Time Enrollment (FTE)

\begin{tabular}{|l|c|c|c|c|c|c|}
\hline & \multicolumn{2}{|c|}{$2009-10$} & \multicolumn{2}{c|}{$2010-11$} & \multicolumn{2}{c|}{$2011-12$} \\
\hline & Funded & Actual & Funded & Actual & Funded & Estimated \\
\hline
\end{tabular} FLORIDA RESIDENTS

\begin{tabular}{|c|c|c|c|c|c|c|}
\hline Lower & 9,378 & 9,182 & 9,378 & 9,468 & 9,378 & 9,431 \\
\hline Upper & 13,361 & 14,384 & 13,361 & 14,548 & 13,361 & 14,580 \\
\hline Grad I & 3,680 & 4,020 & 3,680 & 3,660 & 3,680 & 3,635 \\
\hline Grad II & 854 & 909 & 854 & 1,037 & 854 & 1,132 \\
\hline TOTAL & 27,273 & 28,495 & 27,273 & 28,713 & 27,273 & 28,778 \\
\hline \multicolumn{7}{|c|}{ NON-FLORIDA RESIDENTS } \\
\hline Lower & & 338 & & 413 & & 397 \\
\hline Upper & & 408 & & 451 & & 436 \\
\hline Grad I & & 461 & & 470 & & 371 \\
\hline Grad II & & 258 & & 474 & & 498 \\
\hline TOTAL & 1,400 & 1,465 & 1,400 & 1,808 & 1,400 & 1,702 \\
\hline \multicolumn{7}{|l|}{ TOTAL FTE } \\
\hline Lower & & 9,520 & & 9,881 & & 9,828 \\
\hline Upper & & 14,792 & & 14,999 & & 15,016 \\
\hline Grad I & & 4,481 & & 4,130 & & 4,006 \\
\hline Grad II & & 1,167 & & 1,511 & & 1,630 \\
\hline $\begin{array}{l}\text { Total FTE } \\
\text { (FL Definition) }\end{array}$ & 28,673 & 29,960 & 28,673 & 30,521 & 28,673 & 30,480 \\
\hline $\begin{array}{l}\text { Total FTE } \\
\text { (US Definition) }\end{array}$ & 38,231 & 39,947 & 38,231 & 40,695 & 38,231 & 40,639 \\
\hline
\end{tabular}

Headcount for Medical Doctorates

\begin{tabular}{|l|c|c|c|c|c|c}
\hline $\begin{array}{l}\text { Florida } \\
\text { Residents }\end{array}$ & 480 & 460 & 480 & 449 & 480 & 448 \\
\hline Non-Residents & 0 & 22 & 0 & 24 & 0 & 53 \\
\hline TOTAL & $\mathbf{4 8 0}$ & $\mathbf{4 8 2}$ & $\mathbf{4 8 0}$ & $\mathbf{4 7 3}$ & $\mathbf{4 8 0}$ & $\mathbf{5 0 1}$
\end{tabular}

Notes: Florida definitions of FTE (Undergraduate FTE $=40$ and Graduate FTE $=32$ credit hours per FTE) are used for all items except the row named Total FTE (US Definition), which is based on an

Undergraduate FTE $=30$ and Graduate FTE $=24$ credit hours. Actual Medical headcounts (includes

Medicine, Dentistry, and Veterinary programs) are based on Fall enrollment data.
Section 3 - Enrollment (continued)

TABLE 3B. Enrollment by Location

\begin{tabular}{|c|c|c|c|}
\hline & $\begin{array}{r}2009-10 \\
\text { Actual } \\
\end{array}$ & $\begin{array}{r}2010-11 \\
\text { Actual } \\
\end{array}$ & $\begin{array}{c}2011-12 \\
\text { Estimated }\end{array}$ \\
\hline \multicolumn{4}{|l|}{ TAMPA CAMPUS } \\
\hline Lower & 8,240 & 8,424 & 8,112 \\
\hline Upper & 10,530 & 10,631 & 10,414 \\
\hline Grad I & 2,902 & 2,674 & 2,521 \\
\hline Grad II & 958 & 1,214 & 1,244 \\
\hline TOTAL & 22,630 & 22,944 & 22,290 \\
\hline \multicolumn{4}{|c|}{ SITE: HEALTH-SCIENCE CENTER } \\
\hline Lower & 349 & 386 & 392 \\
\hline Upper & 875 & 953 & 1,099 \\
\hline Grad I & 1,045 & 976 & 1,007 \\
\hline Grad II & 206 & 295 & 381 \\
\hline TOTAL & 2,475 & 2,610 & 2,878 \\
\hline \multicolumn{4}{|c|}{ SITE: POLYTECHNIC } \\
\hline Lower & 52 & 57 & 94 \\
\hline Upper & 754 & 750 & 796 \\
\hline Grad I & 104 & 94 & 103 \\
\hline Grad II & 1 & 0 & 0 \\
\hline TOTAL & 911 & 901 & 992 \\
\hline \multicolumn{4}{|l|}{ SITE: SARASOTA } \\
\hline Lower & 33 & 66 & 119 \\
\hline Upper & 984 & 1,005 & 991 \\
\hline Grad I & 162 & 125 & 113 \\
\hline Grad II & 1 & 2 & 1 \\
\hline TOTAL & 1,181 & 1,198 & 1,225 \\
\hline \multicolumn{4}{|c|}{ SITE: ST. PETERSBURG } \\
\hline Lower & 846 & 947 & 1,112 \\
\hline Upper & 1,650 & 1,661 & 1,716 \\
\hline Grad I & 267 & 260 & 262 \\
\hline Grad II & 1 & 1 & 4 \\
\hline TOTAL & 2,764 & 2,869 & 3,095 \\
\hline
\end{tabular}

VIRTUAL/DISTANCE LEARNING

For the sum of current or planned State-fundable FTE enrollments not served at a physical location.

\begin{tabular}{|c|c|c|c|}
\hline Lower & 1,499 & 1,579 & 1,757 \\
\hline Upper & 3,563 & 3,741 & 4,024 \\
\hline Grad I & 1,216 & 1,243 & 1,248 \\
\hline Grad II & 51 & 59 & 71 \\
\hline TOTAL & $\mathbf{6 , 3 2 9}$ & $\mathbf{6 , 6 2 2}$ & $\mathbf{7 , 1 0 0}$ \\
\hline
\end{tabular}




\section{Section 4 - Undergraduate Education}

\section{TABLE 4A. Baccalaureate Degree Program Changes in AY 2010-11}

\begin{tabular}{|l|c|c|c|c|c|}
\hline Title of Program & $\begin{array}{c}\text { Six-digit } \\
\text { CIP } \\
\text { Code }\end{array}$ & $\begin{array}{c}\text { Degree } \\
\text { Level }\end{array}$ & $\begin{array}{c}\text { Date of } \\
\text { UBOT } \\
\text { Action }\end{array}$ & $\begin{array}{c}\text { Starting } \\
\text { or Ending } \\
\text { Term }\end{array}$ & Comments \\
\hline New Programs & &
\end{tabular}

\section{New Programs} Code Action Term

Health Services/Allied Health/

Health Sciences, General

Public Health, General

\begin{tabular}{|l|l|}
51.0000 & \\
\hline 51.2201 &
\end{tabular}

Bachelor's

Oct. 07,2010 FALL 2011

Information Science/Studies

52.0701

Bachelor's

\begin{tabular}{|l|l|}
\hline Oct. 07,2010 & SPR. 2010 \\
\hline
\end{tabular}

Terminated Programs

\section{Inactive Programs}

Engineering, General

Information Science/Studies

Liberal Arts and Sciences/

14.0101

Bachelor's

Oct. 07,2010 SPR. 2010

Liberal Studies

14.0101 $\quad$ Bachelor's

11.0401

Bachelor's

24.0101

Bachelor's

FALL 2010

\section{New Programs Considered By University But Not Approved}

Note: This table does not include new majors or concentrations added under an existing degree program CIP Code. This table reports the program changes between May 5, 2010 and May 4, 2011. New

Programs are proposed new degree programs that have been completely through the approval process at the university and, if appropriate, the Board of Governors. Terminated Programs are degree programs for which the entire CIP Code has been terminated and removed from the university's inventory of degree programs. Inactive Programs are degree programs for which enrollments have been

temporarily suspended for the entire CIP Code, but the program CIP Code has not been terminated.

\section{Section 4 - Undergraduate Education (continued)}

\section{TABLE 4B. First-Year Persistence Rates}

\begin{tabular}{|c|c|c|c|c|c|}
\hline $\begin{array}{c}\text { Term of Entry } \\
\begin{array}{c}\text { Cohort Size } \\
\text { Full-time FTIC }\end{array}\end{array}$ & Fall 2005 & Fall 2006 & Fall 2007 & Fall 2008 & $\begin{array}{c}\text { Fall 2009 } \\
\text { Preliminary }\end{array}$ \\
\hline \begin{tabular}{|l} 
From Same University \\
\% Still Enrolled
\end{tabular} & 4,399 & 4,142 & 4,395 & 4,306 \\
\hline
\end{tabular}

TABLE 4C. Federal Definition - Undergraduate Progression and Graduation Rates for Full-Time First-Time-in-College (FTIC) Students

\begin{tabular}{|c|c|c|c|c|c|}
\hline Term of Entry & Fall 2001 & Fall 2002 & Fall 2003 & Fall 2004 & $\begin{array}{c}\text { Fall 2005 } \\
\text { Preliminary }\end{array}$ \\
\hline $\begin{array}{c}\text { Cohort Size } \\
\text { Full-time FTIC }\end{array}$ & 3,728 & 4,207 & 4,946 & 4,191 & 4,341 \\
\hline $6-$ Year
\end{tabular}

\section{6 - Year Rates}

From Same University

\begin{tabular}{|c|c|c|c|c|c|}
\hline$\%$ Graduated & $49.3 \%$ & $48.1 \%$ & $48.4 \%$ & $52.4 \%$ & $51.8 \%$ \\
\hline \% Still Enrolled & $10.2 \%$ & $10.6 \%$ & $10.8 \%$ & $9.5 \%$ & $9.2 \%$ \\
\hline \% Success Rate & $59.5 \%$ & $58.7 \%$ & $59.2 \%$ & $61.9 \%$ & $61.1 \%$ \\
\hline
\end{tabular}

Notes: (1) Cohorts are based on undergraduate students who enter the institution in the Fall term (or Summer term and continue into the Fall term); (2) Success Rate measures the percentage of an initial cohort of students who have either graduated or are still enrolled; (3) since degrees can be awarded after the last semester of coursework, the most recent year of data in this table provides preliminary

graduation rate data that may change with the addition of "late degrees". Late degrees reported in conjunction with the IPEDS Graduation Rate Survey due in mid-April will be reflected in the following year. 


\section{Section 4 - Undergraduate Education (continued)}

TABLE 4D. SUS Definition - Undergraduate Progression and Graduation Rates

for First-Time-in-College (FTIC) Students

\begin{tabular}{|c|c|c|c|c|c|}
\hline Term of Entry & Fall 2001 & Fall 2002 & Fall 2003 & Fall 2004 & $\begin{array}{c}\text { Fall 2005 } \\
\text { Preliminary }\end{array}$ \\
\hline $\begin{array}{c}\text { Cohort Size } \\
\text { Full- E Part-time }\end{array}$ & 4,449 & 4,431 & 5,181 & 4,715 & 4,478 \\
\hline 4 & \multicolumn{1}{|c|}{} \\
\hline
\end{tabular}

From Same University

$\%$ Graduated

\% Still Enrolled

\begin{tabular}{l|l|l|l|l}
$18.5 \%$ & $20.4 \%$ & $20.3 \%$ & $23.0 \%$ & $23.8 \%$ \\
\hline $45.2 \%$ & $42.3 \%$ & $42.7 \%$ & $42.8 \%$ & $41.4 \%$ \\
\hline
\end{tabular}

From Other SUS University

$\%$ Graduated

$1.2 \%$

$\%$ Still Enrolled

\begin{tabular}{|l|l|l|l|l}
\hline $1.2 \%$ & $1.3 \%$ & $1.4 \%$ & $1.5 \%$ & $1.6 \%$ \\
\hline $3.8 \%$ & $3.8 \%$ & $3.9 \%$ & $4.8 \%$ & $3.4 \%$ \\
\hline
\end{tabular}

From State University System

\begin{tabular}{|l|l|l|l|l|l|} 
From State University System \\
\hline$\%$ Graduated & $19.8 \%$ & $21.8 \%$ & $21.7 \%$ & $24.5 \%$ & $25.4 \%$ \\
\hline$\%$ Still Enrolled & $49.1 \%$ & $46.1 \%$ & $46.6 \%$ & $47.6 \%$ & $44.8 \%$ \\
\hline$\%$ Success Rate & $68.8 \%$ & $67.8 \%$ & $68.3 \%$ & $72.0 \%$ & $70.1 \%$ \\
\hline
\end{tabular}

6 - Year Rates

From Same University

\begin{tabular}{|c|c|c|c|c|c|}
\hline \% Graduated & $46.7 \%$ & $47.1 \%$ & $47.2 \%$ & $51.3 \%$ & $51.1 \%$ \\
\hline \% Still Enrolled & $11.2 \%$ & $10.7 \%$ & $11.0 \%$ & $9.8 \%$ & $9.4 \%$ \\
\hline
\end{tabular}

$\%$ Still Enrolled

From Other SUS University

\begin{tabular}{|c|c|c|c|c|c|}
\hline$\%$ Graduated & $4.0 \%$ & $4.1 \%$ & $4.4 \%$ & $5.1 \%$ & $4.2 \%$ \\
\hline$\%$ Still Enr
\end{tabular}

From State University System

\begin{tabular}{|l|l|l|l|l|l|}
\hline$\%$ Graduated & $50.7 \%$ & $51.2 \%$ & $51.6 \%$ & $56.4 \%$ & $55.3 \%$ \\
\hline \% Still Enrolled & $13.1 \%$ & $12.2 \%$ & $12.5 \%$ & $11.9 \%$ & $11.0 \%$ \\
\hline \% Success Rate & $63.8 \%$ & $63.4 \%$ & $64.1 \%$ & $68.3 \%$ & $66.3 \%$ \\
\hline
\end{tabular}

Notes: (1) Cohorts are based on undergraduate students who enter the institution in the Fall term (or Summer term and continue into the Fall term); (2) Success Rate measures the percentage of an initial

cohort of students who have either graduated or are still enrolled; (3) since degrees can be awarded after the last semester of coursework, the most recent year of data in this table provides preliminary

graduation rate data that may change with the addition of "late degrees". Late degrees reported in

conjunction with the IPEDS Graduation Rate Survey due in mid-April will be reflected in the following

year.
Section 4 - Undergraduate Education (continued)

TABLE 4E. SUS Definition - Undergraduate Progression and Graduation Rates

for AA Transfer Students

\begin{tabular}{|c|c|c|c|c|c|}
\hline Term of Entry & Fall 2003 & Fall 2004 & Fall 2005 & Fall 2006 & $\begin{array}{c}\text { Fall 2007 } \\
\text { Preliminary }\end{array}$ \\
\hline $\begin{array}{c}\text { Cohort Size } \\
\text { Full- \& Part-time }\end{array}$ & 1,751 & 1,914 & 2,067 & 2,009 & 2,216 \\
\hline 2 & & &
\end{tabular}

2 - Year Rates

From Same University

$\%$ Graduated

$\%$ Still Enrolled

\begin{tabular}{l|l|l|l|l}
$24.8 \%$ & $27.7 \%$ & $26.4 \%$ & $27.6 \%$ & $26.8 \%$ \\
\hline $60.1 \%$ & $57.5 \%$ & $58.9 \%$ & $58.5 \%$ & $59.4 \%$ \\
\hline
\end{tabular}

From Other SUS University

\begin{tabular}{|c|c|c|c|c|c|}
\hline$\%$ Graduated & $0.2 \%$ & $0.3 \%$ & $0.2 \%$ & $0.1 \%$ & $0.1 \%$ \\
\hline
\end{tabular}

\begin{tabular}{|l|l|l|l|l|l|}
\hline$\%$ Still Enrolled & $1.1 \%$ & $2.0 \%$ & $1.8 \%$ & $1.5 \%$ & $1.3 \%$
\end{tabular}

From State University System

\begin{tabular}{|l|l|l|l|l|l|}
\hline$\%$ Graduated & $25.0 \%$ & $28.0 \%$ & $26.6 \%$ & $27.7 \%$ & $26.9 \%$ \\
\hline
\end{tabular}

\begin{tabular}{|l|l|l|l|l|l|}
\hline$\%$ Still Enrolled & $25.0 \%$ & $28.0 \%$ & $26.6 \%$ & $27.7 \%$ & $26.9 \%$ \\
\hline
\end{tabular}

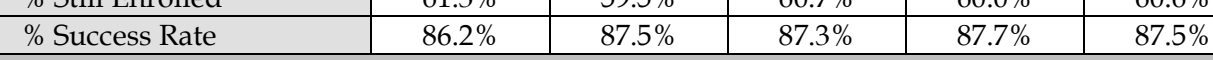

4 - Year Rates

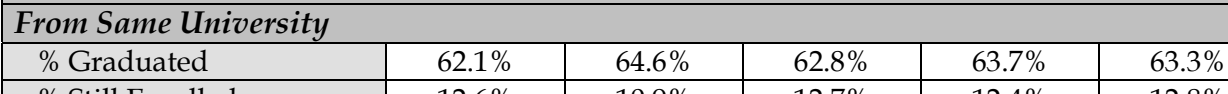

$\%$ Still Enrolled

12

From Other SUS University

\begin{tabular}{|l|l|l|l|l|l|}
\hline$\%$ Graduated & $1.1 \%$ & $1.4 \%$ & $1.4 \%$ & $0.7 \%$ & $1.0 \%$ \\
\hline
\end{tabular}

\begin{tabular}{|l|l|l|l|l|l|}
\hline$\%$ Still Enrolled & $0.5 \%$ & $1.2 \%$ & $0.7 \%$ & $1.2 \%$ & $1.2 \%$ \\
\hline
\end{tabular}

From State University System

\begin{tabular}{|l|c|c|c|c|c|}
\hline$\%$ Graduated & $67.2 \%$ & $67.8 \%$ & $67.1 \%$ & $68.1 \%$ & $64.3 \%$ \\
\hline
\end{tabular}

\begin{tabular}{|l|l|l|l|l|l|}
\hline \% Still Enrolled & $13.1 \%$ & $12.1 \%$ & $13.4 \%$ & $13.6 \%$ & $14.0 \%$ \\
\hline
\end{tabular}

\begin{tabular}{|l|l|l|l|l|l|}
\hline \% Success Rate & $76.4 \%$ & $78.1 \%$ & $77.5 \%$ & $78.0 \%$ & $78.3 \%$ \\
\hline
\end{tabular}

Notes: (1) Cohorts are based on undergraduate students who enter the institution in the Fall term (or

Summer term and continue into the Fall term); (2) Success Rate measures the percentage of an initial

cohort of students who have either graduated or are still enrolled; (3) since degrees can be awarded after

the last semester of coursework, the most recent year of data in this table provides preliminary

graduation rate data that may change with the addition of "late degrees". Late degrees reported in

conjunction with the IPEDS Graduation Rate Survey due in mid-April will be reflected in the following

year. 


\section{Section 4 - Undergraduate Education (continued)}

TABLE 4F. SUS Definition - Undergraduate Progression and Graduation Rates

for Other Transfer Students

\begin{tabular}{|c|c|c|c|c|c|}
\hline Term of Entry & Fall 2002 & Fall 2003 & Fall 2004 & Fall 2005 & $\begin{array}{c}\text { Fall 2006 } \\
\text { Preliminary }\end{array}$ \\
\hline $\begin{array}{c}\text { Cohort Size } \\
\text { Full- \& Part-time }\end{array}$ & 2,217 & 2,399 & 2,495 & 2,498 & 2,592 \\
\hline
\end{tabular}

\section{5 - Year Rates}

From Same University

\begin{tabular}{|c|c|c|c|c|c|}
\hline$\%$ Graduated & $52.1 \%$ & $55.5 \%$ & $55.6 \%$ & $53.4 \%$ & $59.8 \%$ \\
\hline
\end{tabular}

From Other SUS University

\begin{tabular}{|c|c|c|c|c|c|}
\hline$\%$ Graduated & $2.2 \%$ & $2.0 \%$ & $1.6 \%$ & $1.3 \%$ & $2.4 \%$ \\
\hline
\end{tabular}

\begin{tabular}{|l|l|l|l|l|l}
\hline \% Still Enrolled & $0.7 \%$ & $0.7 \%$ & $0.8 \%$ & $0.8 \%$ & $0.5 \%$ \\
\hline
\end{tabular}

From State University System

\begin{tabular}{|c|c|c|c|c|c|}
\hline$\%$ Graduated & $54.3 \%$ & $57.5 \%$ & $57.2 \%$ & $54.7 \%$ & $62.2 \%$ \\
\hline$\%$ Still $\%$ & $7.8 \%$ & $7.5 \%$ & $7.2 \%$ & $7.5 \%$ \\
\hline
\end{tabular}

\begin{tabular}{|l|c|c|c|c|c|}
\hline$\%$ Still Enrolled & $8.5 \%$ & $7.8 \%$ & $7.5 \%$ & $7.2 \%$ & $7.5 \%$ \\
\hline
\end{tabular}

\begin{tabular}{|c|c|c|c|c|c|}
\hline$\%$ Success Rate & $62.8 \%$ & $65.3 \%$ & $64.6 \%$ & $61.9 \%$ & $69.7 \%$ \\
\hline
\end{tabular}

Notes: (1) Cohorts are based on undergraduate students who enter the institution in the Fall term (or

Summer term and continue into the Fall term); (2) Success Rate measures the percentage of an initial

cohort of students who have either graduated or are still enrolled; (3) since degrees can be awarded after

the last semester of coursework, the most recent year of data in this table provides preliminary

graduation rate data that may change with the addition of "late degrees". Late degrees reported in

conjunction with the IPEDS Graduation Rate Survey due in mid-April will be reflected in the following

year.

\begin{tabular}{|c|c|c|c|c|c|}
\hline \multicolumn{1}{|c|}{ TABLE 4G. Baccalaureate Degrees Awarded } \\
\hline & $\mathbf{2 0 0 6 - 0 7}$ & $\mathbf{2 0 0 7 - 0 8}$ & $\mathbf{2 0 0 8 - 0 9}$ & $\mathbf{2 0 0 9 - 1 0}$ & $\mathbf{2 0 1 0 - 1 1}$ \\
\hline Baccalaureate Degrees & 6,736 & 7,086 & 7,479 & 7,891 & 8,190 \\
\hline
\end{tabular}

\begin{tabular}{|c|c|c|c|c|c|}
\hline \multicolumn{1}{|c|}{ TABLE 4H. Baccalaureate Degrees Awarded in Areas of Strategic Emphasis } \\
\hline & $\mathbf{2 0 0 6 - 0 7}$ & $\mathbf{2 0 0 7 - 0 8}$ & $\mathbf{2 0 0 8 - 0 9}$ & $\mathbf{2 0 0 9 - 1 0}$ & $\mathbf{2 0 1 0 - 1 1}$ \\
\hline Education & 94 & 105 & 112 & 105 & 109 \\
\hline Health Professions & 443 & 420 & 435 & 437 & 439 \\
\hline $\begin{array}{c}\text { Science, Technology, } \\
\text { Engineering, and Math }\end{array}$ & 1,255 & 1,299 & 1,395 & 1,536 & 1,635 \\
\hline $\begin{array}{c}\text { Security and Emergency } \\
\text { Services }\end{array}$ & 366 & 394 & 412 & 458 & 475 \\
\hline Globalization & 427 & 445 & 470 & 490 & 526 \\
\hline SUBTOTAL & $\mathbf{2 , 5 8 5}$ & $\mathbf{2 , 6 6 3}$ & $\mathbf{2 , 8 2 4}$ & $\mathbf{3 , 0 2 6}$ & $\mathbf{3 , 1 8 4}$ \\
\hline
\end{tabular}

Section 4 - Undergraduate Education (continued)

TABLE 4I. Baccalaureate Degrees Awarded to Underrepresented Groups

\begin{tabular}{|l|c|c|c|}
\hline $2006-07$ & $2007-08$ & $2008-09$ & $2009-10$ \\
\hline
\end{tabular}

2010-11

\section{Non-Hispanic Black}

$$
\text { Number of }
$$

Baccalaureate Degrees

Percentage of All

Baccalaureate Degrees

\begin{tabular}{|c|c|c|c|c|}
\hline 774 & 811 & $\begin{array}{c}899 \\
\text { Increase* }^{*}\end{array}$ & 872 & 921 \\
\hline $12.1 \%$ & $12.0 \%$ & $\begin{array}{c}12.4 \% \\
\text { Increase }\end{array}$ & $11.4 \%$ & $11.6 \%$ \\
\hline
\end{tabular}

Hispanic

$$
\text { Number of }
$$

Baccalaureate Degrees

Percentage of All

Baccalaureate Degrees

\begin{tabular}{|c|c|c|c}
\hline 685 & 764 & $\begin{array}{c}875 \\
\text { Increase* }^{*}\end{array}$ \\
\hline $10.7 \%$ & $11.3 \%$ & $\begin{array}{c}12.1 \% \\
\text { Increase* }\end{array}$ \\
\hline
\end{tabular}

\begin{tabular}{l|l}
941 & 1,140 \\
\hline
\end{tabular}

Pell-Grant Recipients

$$
\text { Number of }
$$

Baccalaureate Degrees

Percentage of All

Baccalaureate Degrees

\begin{tabular}{|c|c|c|c|c|}
\hline 2,633 & 2,662 & $\begin{array}{c}2,853 \\
\text { Maintain* }\end{array}$ & 3,202 & 3,221 \\
\hline $40.2 \%$ & $38.4 \%$ & $\begin{array}{c}38.8 \% \\
\text { Maintain* }\end{array}$ & $41.1 \%$ & $39.4 \%$ \\
\hline
\end{tabular}

Note: Pell-Grant recipients are defined as those students who have received a Pell grant from any SUS Institution within six years of graduation. This does not include degrees awarded to students whose race/ethnicity code is missing (or not reported) or for students who are non-resident aliens.

Note*: Directional goals for the 2012-13 year were established in the 2010 University Work Plan.

TABLE 4J. Baccalaureate Completion Without Excess Credit Hours

\begin{tabular}{|c|c|c|c|c|c|}
\hline & Fall 2006 & Fall 2007 & Fall 2008 & Fall 2009 & Fall 2010 \\
\hline $\begin{array}{c}\text { Number of } \\
\text { Course Sections }\end{array}$ & 3,118 & 3,275 & 3,023 & 3,157 & 3,261 \\
\hline \multicolumn{6}{|c|}{ Percentage of Undergraduate Course Sections by Class Size } \\
\hline Fewer than 30 Students & $59 \%$ & $61 \%$ & $57 \%$ & $59 \%$ & $58 \%$ \\
\hline 30 to 49 Students & $28 \%$ & $27 \%$ & $28 \%$ & $28 \%$ & $28 \%$ \\
\hline 50 to 99 Students & $10 \%$ & $10 \%$ & $12 \%$ & $11 \%$ & $11 \%$ \\
\hline 100 or More Students & $3 \%$ & $3 \%$ & $3 \%$ & $3 \%$ & $3 \%$ \\
\hline
\end{tabular}

\begin{tabular}{c|c|c|c|c|c|}
\hline $\begin{array}{c}\text { \% of Total Baccalaureate } \\
\begin{array}{c}\text { Degrees Awarded } \\
\text { Within 110\% of Hours } \\
\text { Required for Degree }\end{array}\end{array}$ & 2006-07 & $\mathbf{2 0 0 7 - 0 8}$ & $\mathbf{2 0 0 8 - 0 9}$ & $\mathbf{2 0 0 9 - 1 0}$ & $\mathbf{2 0 1 0 - 1 1}$ \\
\hline
\end{tabular}

\section{TABLE 4K. Undergraduate Course Offerings}




\section{Section 4 - Undergraduate Education (continued)}

\section{TABLE 4L. Faculty Teaching Undergraduates}

\begin{tabular}{|l|l|l|l|r|}
$2006-07$ & $2007-08$ & $2008-09$ & $2009-10$ & $2010-11$ \\
\hline
\end{tabular}

Percentage of Credit Hours Taught by:

\begin{tabular}{|l|c|c|c|c|c|}
\hline Faculty & $60 \%$ & $61 \%$ & $63 \%$ & $65 \%$ & $66 \%$ \\
\hline Adjunct Faculty & $24 \%$ & $24 \%$ & $23 \%$ & $21 \%$ & $19 \%$ \\
\hline Graduate Students & $16 \%$ & $14 \%$ & $14 \%$ & $13 \%$ & $14 \%$ \\
\hline Other Instructors & $1 \%$ & $0 \%$ & $0 \%$ & $1 \%$ & $1 \%$ \\
\hline
\end{tabular}

Note: The definition of faculty varies for Tables $4 \mathrm{~L}, 4 \mathrm{M}$ and $4 \mathrm{~N}$. For Faculty Teaching Undergraduates,

the definition of faculty is based on pay plans 01,02 , and 22

\section{TABLE 4M. Undergraduate Instructional Faculty Compensation}

\begin{tabular}{|l|c|c|c|c|c|}
\hline & $\mathbf{2 0 0 6 - 0 7}$ & $\mathbf{2 0 0 7 - 0 8}$ & $\mathbf{2 0 0 8 - 0 9}$ & $\mathbf{2 0 0 9 - 1 0}$ & $\mathbf{2 0 1 0 - 1 1}$ \\
\hline $\begin{array}{l}\text { Average Salary and } \\
\text { Benefits for Faculty }\end{array}$ & $\$ 90,111$ & $\$ 93,079$ & $\$ 89,791$ & $\$ 93,039$ & $\$ 90,120$ \\
$\begin{array}{l}\text { Who Teach at Least One } \\
\text { Undergraduate Course }\end{array}$ & & & & \\
\hline $\begin{array}{l}\text { Note: The definition of faculty varies for Tables 4L, 4M and 4N. For Undergraduate Instructional Faculty } \\
\text { Compensation, the definition of faculty is based on pay plan 22. }\end{array}$ \\
\hline
\end{tabular}

\section{TABLE 4N. Student/Faculty Ratio}

Student-to-Faculty Ratio

\begin{tabular}{|l|c|c|c|c|} 
Fall 2006 & Fall 2007 & Fall 2008 & Fall 2009 & Fall 2010 \\
\hline
\end{tabular}

Note: The definition of faculty varies for Tables $4 \mathrm{~L}, 4 \mathrm{M}$ and $4 \mathrm{~N}$. For Student/Faculty Ratio, the

definition of faculty is consistent with Common Data Set reporting (which counts full-time equivalent instructional faculty as full-time faculty plus $1 / 3$ part-time faculty).

\begin{tabular}{|l|l|c|c|c|c|}
\hline TABLE 4O. Professional Licensure/Certification Exams for Undergraduate Programs \\
\hline & $\mathbf{2 0 0 6 - 0 7}$ & $\mathbf{2 0 0 7 - 0 8}$ & $\mathbf{2 0 0 8 - 0 9}$ & $\mathbf{2 0 0 9 - 1 0}$ & $\mathbf{2 0 1 0 - 1 1}$ \\
\hline Nursing: National Council Licensure Examination for Registered Nurses \\
\hline Examinees & 95 & 152 & 157 & 151 & 169 \\
\hline Pass Rate & $82.1 \%$ & $92.1 \%$ & $98.1 \%$ & $96.0 \%$ & $95.9 \%$ \\
\hline National Benchmark & $88.3 \%$ & $86.4 \%$ & $87.5 \%$ & $89.5 \%$ & $88.7 \%$ \\
\hline
\end{tabular}

\section{Section 4 - Undergraduate Education (continued)}

\section{TABLE 4P. Tuition Differential Fee}

\begin{tabular}{|c|c|c|c|}
\hline Total Revenues Generated & $\mathbf{2 0 0 9 - 1 0}$ & $\mathbf{2 0 1 0 - 1 1}$ & $\begin{array}{c}\mathbf{2 0 1 1 - 1 2} \\
\text { Projected }\end{array}$ \\
\hline $\begin{array}{c}\text { By the Tuition Differential } \\
\text { Unduplicated Count of Students } \\
\text { Receiving Financial Aid Award Funded by } \\
\text { Tuition Differential Revenues }\end{array}$ & $\mathbf{\$ 7 , 4 5 8 , 4 9 5}$ & $\$ 14,376,755$ & $\$ 20,996,275$ \\
\hline $\begin{array}{c}\text { Average Amount of Awards } \\
\text { Funded by Tuition Differential Revenues } \\
\text { (per student receiving an award) }\end{array}$ & $\$ 1,043$ & $\$ 1,346$ & \\
\hline $\begin{array}{c}\text { Number of Students Eligible for a } \\
\text { Florida Student Assistance Grant (FSAG) }\end{array}$ & 7,102 & 7,856 & \\
\hline $\begin{array}{c}\text { Number of FSAG-Eligible Students } \\
\text { Receiving a Waiver } \\
\text { of the Tuition Differential }\end{array}$ & 0 & 0 & \\
\hline $\begin{array}{c}\text { Value of Tuition Differential Waivers } \\
\text { Provided to FSAG-Eligible Students }\end{array}$ & 0 & 0 & \\
\hline
\end{tabular}




\section{Section 5 - Graduate Education}

\begin{tabular}{|c|c|c|c|c|c|c|}
\hline TABLE 5A. Graduate Degree Program Changes in AY 2010-11 \\
\hline Title of Program & $\begin{array}{c}\text { Six-digit } \\
\text { CIP } \\
\text { Code }\end{array}$ & $\begin{array}{c}\text { Degree } \\
\text { Level }\end{array}$ & $\begin{array}{c}\text { Date of } \\
\text { UBOT } \\
\text { Action }\end{array}$ & $\begin{array}{c}\text { Starting } \\
\text { or Ending } \\
\text { Term }\end{array}$ & $\begin{array}{c}\text { Date of } \\
\text { Board of } \\
\text { Governors } \\
\text { Action }\end{array}$ & Comments \\
\hline
\end{tabular}

\section{New Programs}

Education/Teaching of Individuals with Autism

Economics, General

Hospitality Administration/

Management, General

Terminated Programs

Inactive Programs

\begin{tabular}{|l|l|l|l|l|}
\hline Playwriting and Screenwriting & 50.0504 & Masters & & Fall 2010 \\
\hline
\end{tabular}

\section{New Programs Considered By University But Not Approved}

Note: This table does not include new majors or concentrations added under an existing degree program CIP Code. This table reports the program changes between May 5, 2010 and May 4, 2011. New Programs are proposed new degree programs that have been completely through the approval process at the university and, if appropriate, the Board of Governors. Terminated Programs are degree programs for which the entire CIP Code has been terminated and removed from the university's inventory of degree programs. Inactive Programs are degree programs for which enrollments have been temporarily suspended for the entire CIP Code, but the program CIP Code has not been terminated.

\section{TABLE 5B. Graduate Degrees Awarded}

\begin{tabular}{|c|c|c|c|c|c|}
\hline & $\mathbf{2 0 0 6 - 0 7}$ & $\mathbf{2 0 0 7 - 0 8}$ & $\mathbf{2 0 0 8 - 0 9}$ & $\mathbf{2 0 0 9 - 1 0}$ & $\mathbf{2 0 1 0 - 1 1}$ \\
\hline TOTAL & $\mathbf{2 , 4 5 8}$ & $\mathbf{2 , 6 8 6}$ & $\mathbf{2 , 8 8 4}$ & $\mathbf{2 , 9 4 4}$ & $\mathbf{3 , 0 0 2}$ \\
\hline Masters and Specialist & 2,113 & 2,314 & 2,482 & 2,544 & 2,577 \\
\hline Research Doctoral & 223 & 229 & 248 & 244 & 269 \\
\hline Professional Doctoral & 122 & 143 & 154 & 156 & 156 \\
\hline a) Medicine & 116 & 115 & 114 & 116 & 109 \\
\hline b) Law & 0 & 0 & 0 & 0 & 0 \\
\hline c) Pharmacy & 0 & 0 & 0 & 0 & 0 \\
\hline
\end{tabular}

Note: The total number of Professional Doctoral degrees includes other programs that are not specifically identified in lines $a, b$, and $c$.
Section 5 - Graduate Education (continued)

TABLE 5C. Graduate Degrees Awarded in Areas of Strategic Emphasis

\begin{tabular}{|c|c|c|c|c|c|}
\hline & $\mathbf{2 0 0 6 - 0 7}$ & $\mathbf{2 0 0 7 - 0 8}$ & $\mathbf{2 0 0 8 - 0 9}$ & $\mathbf{2 0 0 9 - 1 0}$ & $\mathbf{2 0 1 0 - 1 1}$ \\
\hline Education & 193 & 194 & 234 & 188 & 170 \\
\hline Health Professions & 428 & 429 & 506 & 566 & 662 \\
\hline $\begin{array}{c}\text { Science, Technology, } \\
\text { Engineering, and Math }\end{array}$ & 454 & 544 & 530 & 616 & 637 \\
\hline $\begin{array}{c}\text { Security and Emergency } \\
\text { Services }\end{array}$ & 6 & 36 & 53 & 40 & 31 \\
\hline Globalization & 42 & 46 & 41 & 54 & 49 \\
\hline SUBTOTAL & $\mathbf{1 , 1 2 3}$ & $\mathbf{1 , 2 4 9}$ & $\mathbf{1 , 3 6 4}$ & $\mathbf{1 , 4 6 4}$ & $\mathbf{1 , 5 4 9}$ \\
\hline
\end{tabular}

TABLE 5D. Professional Licensure Exams - Graduate Programs

Medicine: US Medical Licensing Exam (Step 1)

\begin{tabular}{|l|c|c|c|c|c|}
\hline & $\mathbf{2 0 0 7}$ & $\mathbf{2 0 0 8}$ & $\mathbf{2 0 0 9}$ & $\mathbf{2 0 1 0}$ & $\begin{array}{c}\mathbf{2 0 1 1} \\
\text { Preliminary }\end{array}$ \\
\hline Examinees & 112 & 117 & 117 & 114 & 110 \\
\hline Pass Rate & $97 \%$ & $96 \%$ & $95 \%$ & $94 \%$ & $92 \%$ \\
\hline National Benchmark & $94 \%$ & $93 \%$ & $93 \%$ & $92 \%$ & $99 \%$ \\
\hline
\end{tabular}

Medicine: US Medical Licensing Exam (Step 2) Clinical Knowledge

\begin{tabular}{|l|c|c|c|c|c|}
\hline & $\mathbf{2 0 0 6 - 0 7}$ & $\mathbf{2 0 0 7 - 0 8}$ & $\mathbf{2 0 0 8 - 0 9}$ & $\mathbf{2 0 0 9 - 1 0}$ & $\begin{array}{c}\mathbf{2 0 1 0 - 1 1} \\
\text { Preliminary }\end{array}$ \\
\hline Examinees & 111 & 101 & 121 & 96 & 90 \\
\hline Pass Rate & $100 \%$ & $100 \%$ & $100 \%$ & $100 \%$ & $100 \%$ \\
\hline National Benchmark & $95 \%$ & $96 \%$ & $96 \%$ & $97 \%$ & $97 \%$ \\
\hline
\end{tabular}

Medicine: US Medical Licensing Exam (Step 2) Clinical Skills

\begin{tabular}{|l|c|c|c|c|c|} 
& $\mathbf{2 0 0 6 - 0 7}$ & $\mathbf{2 0 0 7 - 0 8}$ & $\mathbf{2 0 0 8 - 0 9}$ & $\mathbf{2 0 0 9 - 1 0}$ & $\begin{array}{c}\mathbf{2 0 1 0 - 1 1} \\
\text { Preliminary }\end{array}$ \\
\hline Examinees & 126 & 92 & 118 & 109 & 49 \\
\hline Pass Rate & $95 \%$ & $97 \%$ & $97 \%$ & $95 \%$ & $100 \%$ \\
\hline National Benchmark & $97 \%$ & $97 \%$ & $97 \%$ & $97 \%$ & $97 \%$ \\
\hline
\end{tabular}

Physical Therapy: National Physical Therapy Examinations

\begin{tabular}{|l|c|c|c|c|c|}
\hline & $\mathbf{2 0 0 4 - 0 6}$ & $\mathbf{2 0 0 5 - 0 7}$ & $\mathbf{2 0 0 6 - 0 8}$ & $\mathbf{2 0 0 7 - 0 9}$ & $\mathbf{2 0 0 8 - 1 0}$ \\
\hline Examinees & 71 & 51 & 43 & 51 & 81 \\
\hline Pass Rate & $86 \%$ & $82 \%$ & $88 \%$ & $86 \%$ & $85 \%$ \\
\hline National Benchmark & $80 \%$ & $86 \%$ & $86 \%$ & $87 \%$ & $87 \%$ \\
\hline
\end{tabular}

Note: Three-year average pass rate for first-time examinees (includes PT assistants) on the National Physical Therapy Examinations by exam year. We have chosen to compute a three-year average of these rates, rather than report the annual averages, because of the relatively small cohort sizes compared to other licensed professional programs. USF's Physical Therapy program transitioned from a 2-year

Master's level to 3-year Doctoral degree program and did not have any examinees tested in 2007. 
Section 6 - Research and Economic Development

\begin{tabular}{|c|c|c|c|c|c|}
\hline & 2005-06 & 2006-07 & 2007-08 & 2008-09 & 2009-10 \\
\hline \multicolumn{6}{|l|}{ R\&D Expenditures } \\
\hline $\begin{array}{l}\text { Federally Funded } \\
\text { Expenditures } \\
\text { (Thousand \$) }\end{array}$ & $\$ 157,324$ & $\$ 171,272$ & $\$ 189,282$ & $\$ 213,163$ & $\$ 246,016$ \\
\hline $\begin{array}{l}\text { Total Expenditures } \\
\text { (Thousand \$) }\end{array}$ & $\$ 304,804$ & $\$ 337,169$ & $\$ 342,665$ & $\$ 371,037$ & $\$ 390,828$ \\
\hline $\begin{array}{l}\text { Total R\&D Expenditures } \\
\text { Per Full-Time, Tenured, } \\
\text { Tenure-Earning Faculty } \\
\text { Member }(\$)\end{array}$ & $\$ 253,159$ & $\$ 278,652$ & $\$ 291,630$ & $\$ 313,641$ & $\$ 327,318$ \\
\hline \multicolumn{6}{|l|}{ Technology Transfer } \\
\hline Invention Disclosures & 109 & 110 & 139 & 141 & 161 \\
\hline Total U.S. Patents Issued & 29 & 31 & 31 & 36 & 66 \\
\hline $\begin{array}{l}\text { Patents Issued Per } 1,000 \\
\text { Full-Time, Tenure and } \\
\text { Tenure-Earning Faculty }\end{array}$ & 24 & 26 & 26 & 28 & 52 \\
\hline $\begin{array}{l}\text { Total Number of Licenses/ } \\
\text { Options Executed }\end{array}$ & 21 & 23 & 28 & 25 & 37 \\
\hline $\begin{array}{l}\text { Total Licensing Income } \\
\text { Received (\$) }\end{array}$ & $\$ 1,704,025$ & $\$ 2,099,712$ & $\$ 1,831,000$ & $\$ 1,300,000$ & $\$ 17,900,000$ \\
\hline $\begin{array}{l}\text { Total Number of Start-Up } \\
\text { Companies }\end{array}$ & 6 & 4 & 5 & 3 & 5 \\
\hline \multicolumn{6}{|c|}{$\begin{array}{l}\text { Note: Awards and Expenditures are based on the National Science Foundation's annual Survey of R\&D } \\
\text { Expenditures at Universities and Colleges (data include Science \& Engineering and non-Science \& } \\
\text { Engineering awards). Technology Transfer data are based on the Association of University Technology } \\
\text { Managers Annual Licensing Survey. }\end{array}$} \\
\hline
\end{tabular}

This page is intentionally left blank. 


\section{Section 6 - Research and Economic Development (continued)}

\section{TABLE 6B. Centers of Excellence}

\begin{tabular}{|c|c|c|c|}
\hline Name of Center: & $\begin{array}{l}\text { Center for Drug Discovery and } \\
\text { Innovation (formerly FCoE-BITT) }\end{array}$ & \multirow{2}{*}{$\begin{array}{l}\text { Cumulative } \\
\text { (since inception } \\
\text { to June 2011) }\end{array}$} & \multirow{2}{*}{$\begin{array}{c}\text { Fiscal Year } \\
2010-11\end{array}$} \\
\hline Year Created: & $2006-07$ & & \\
\hline
\end{tabular}

Research Effectiveness

Only includes data for activities directly associated with the Center. Does not include the non-Center activities for faculty who are associated with the Center.

\begin{tabular}{|l|}
\hline Number of Competitive Grants Applied For \\
\hline Value of Competitive Grants Applied For (\$) \\
\hline
\end{tabular}

Number of Competitive Grants Received

Value of Competitive Grants Received (\$)

Total Research Expenditures (\$)

Number of Publications in Refereed Journals

From Center Research

Number of Invention Disclosures

Number of Licenses/Options Executed

Licensing Income Received (\$)

Collaboration Effectiveness

Only reports on relationships that include financial or in-kind support.

Collaborations with Other Postsecondary Institutions

Collaborations with Private Industry

Collaborations with K-12 Education Systems/Schools

Undergraduate and Graduate Students Supported

with Center Funds

Economic Development Effectiveness

Number of Start-Up companies

with a physical presence, or employees, in Florida

Jobs Created By Start-Up Companies

Associated with the Center

Specialized Industry Training and Education

Private-sector Resources Used to Support

the Center's Operations

Narrative Comments on next page.

\section{Section 6 - Research and Economic Development (continued)}

TABLE 6B. Centers of Excellence

\section{Name of Center}

Center for Drug Discovery and Innovation

Narrative Comments [Most Recent Year]:

(1) November 2010, Bill Baker, Ph.D., became the Director of FCoE-BITT. In August of 2011 FCoE-BITT officially became known as the Center for Drug Discovery and Innovation, this change marked the transition to the new objective of early drug discovery. (2) In June of this year Marilyn Barger, Ph.D., Director of FLATE and the CDDI office at HCC made a presentation on workforce efforts at the High Impact Technology and Exchange Conference in San Francisco. (3) Through the SEED Grant program

Marilyn Barger, Ph.D., disseminated information at several regional events to high school and community college students. (4) CDDI through its partnership with Hillsborough Community College participated in BEACON, which is a new statewide collaboration of state and community colleges. (5) College students and faculty members toured two industry sites. (6) Conducted a survey amongst regional industries for biotechnology workforce needs. (7) Ran three one day hands on biotechnology workshop for forty total regional science teachers. (8) Provided support for two faculty members to attend a four day regulatory workshop. 
Section 6 - Research and Economic Development (continued)

TABLE 6C. State University Research Commercialization Assistance Grants

\begin{tabular}{|l|c|c|c|}
\hline \multicolumn{1}{|c|}{ Project Name by Type of Grant } & $\begin{array}{c}\text { Year } \\
\text { Grant } \\
\text { Awarded }\end{array}$ & \multicolumn{2}{c|}{$\begin{array}{c}\text { Cumulative } \\
\text { Awards }\end{array}$} \\
\hline Phase I Grants & & & \\
\hline Early Stage RAID & FY2008 & $\$ 50,000$ & $\$ 50,000$ \\
\hline Phase II Grants & & & \\
\hline Platinum Compounds & FY2008 & $\$ 50,000$ & $\$ 50,000$ \\
\hline Phase III Grants & & & \\
\hline MDI Partners, LLC & FY2011 & $\$ 185,000$ & $\$ 47,513$ \\
\hline Rehab Ideas, Inc. & FY2011 & $\$ 150,000$ & $\$ 90,226$ \\
\hline Natura Therapeutics, Inc. & FY2011 & $\$ 65,000$ & $\$ 58,500$ \\
\hline Total for all SURCAG Grants & & $\$ \mathbf{5 0 0 , 0 0 0}$ & $\mathbf{\$ 2 9 6 , 2 3 9}$ \\
\hline
\end{tabular}

Narrative Comments: For each project, provide a brief update on (1) the project's progress

towards completing its key milestones/deliverables; and (2) the project's return on investment for the university and state.

Phase I Grants

USF Phase I Early Stage RAID: (1) Key milestones for this project included the preparation, submission, review, and award of multiple grant applications. Two staff members were trained in the application process. Over the course of the project we participated in the submission of a total of 14 commercialization grant applications: three RAID (now known as NExT) applications to the National Cancer Institute; as well as three Technology Transfer Fund (TTF) and two Technology Transfer Commercialization Proposal (TTCP) applications. The RAID/Next application materials were used with some revision for submission to other programs for funding. (2) The return on investment for this Grant is multifold. We

successfully obtained $\$ 100,000$ in grants towards the commercialization of University technologies and are continuing to pursue the preparation of additional RAID/NEXT applications. These grants are producing tangible work- two new personnel hires, additional validation of our research results, and clinical trials.

\section{Phase II Grants}

USF Phase II Platinum Compounds: (1) Key milestones for this project included creating a business plan for the commercialization of anti-cancer drug compounds. During this process, we evaluated two classes of drugs, platinum compounds and palmerolides. Due to technical difficulties in synthesizing the platinum compounds, we moved forward with the

palmerolides. A business plan was created, and an SBIR was submitted with a commercial partner. (2) The return on investment for this Grant include the independent assessment of multiple compounds for synthesis, and the potential for preclinical testing should the SBIR be awarded, which greatly increases the potential commercial value of the technologies should they be licensed.
Section 6 - Research and Economic Development (continued)

TABLE 6C. State University Research Commercialization Assistance Grants

Narrative Comments (continued):

\section{Phase III Grants}

\section{Partners:}

The overall goal for this grant was to finalize the design of the sheath, gear up for manufacturing, submit an application for FDA approval, and ultimately get commercial product on the market. In support of this goal and milestones proposed in the grant, MDI designed and built 100 prototypes and established a distribution partnership. Next steps in support of clinical validation include a 75 patient user preference study followed quickly by regulatory clearance and product launch.

\section{Rehab Ideas:}

The overall goal for this grant was to commercialize five innovative products designed specifically for individuals with disabilities including the Mobili-T Rover, Backpack Retriever TrayAway, Folding Crutch and Sideways Wheelchair Kit. In support of this goal and several milestones proposed in the grant, Rehab Ideas hired two part-time staff members through their manufacturing partner, and retooled production lines to support the latest design specifications for four of the five products. Marketing efforts were very successful and stimulated commercial scale manufacturing for the Mobili-T Rover (5 units), Backpack Retriever ( 25 units), and TrayAway ( 25 units). Future work will increase capacity and focus on bringing the Folding Crutch and Sideways Wheelchair Kit further along in commercial production

\section{Natura Therapeutics:}

Natura's overall goal for this grant was to develop and commercialize a combination product for supporting cellular health and weight loss, NutraStem ${ }^{\circledR}$ Slim. In support of this goal and accomplishing the first milestone proposed in the grant, Natura conducted several proof of principle studies in laboratory models of obesity and cellular health. The data established a dose that was beneficial for stem cell health, and a dose that was beneficial for promoting weight loss. Ongoing studies are planned to optimize a single dosage for both optimal health effects before moving quickly to manufacturing and product launch. 
Section 6 - Research and Economic Development (continued)

\begin{tabular}{|c|c|c|c|c|c|c|}
\hline \multirow[b]{2}{*}{$\begin{array}{l}\text { World Class } \\
\text { Scholar(s) }\end{array}$} & \multirow[b]{2}{*}{$\begin{array}{l}\text { Scholar's } \\
\text { Field }\end{array}$} & \multicolumn{2}{|c|}{ Grant Dollars } & \multicolumn{3}{|c|}{$\begin{array}{l}\text { Report the cumulative activity } \\
\text { since each scholar's award. }\end{array}$} \\
\hline & & $\begin{array}{c}\text { Amount } \\
\text { Awarded } \\
\text { (Thousand \$) }\end{array}$ & $\begin{array}{l}\text { Cumulative } \\
\text { Amount } \\
\text { Expended } \\
\text { (Thousand \$) }\end{array}$ & $\begin{array}{l}\text { External } \\
\text { Research } \\
\text { Awards } \\
\text { (Thousand \$) }\end{array}$ & $\begin{array}{l}\text { Patents } \\
\text { Filed / } \\
\text { Issued }\end{array}$ & $\begin{array}{l}\text { Licensing } \\
\text { Revenues } \\
\text { Generated } \\
\quad(\$)\end{array}$ \\
\hline John Adams & $\begin{array}{l}\text { Global Health } \\
\text { (malaria control) }\end{array}$ & 2,000 & 2,000 & $\$ 8,190$ & 1 & 0 \\
\hline Richard Gitlin & $\begin{array}{l}\text { Electrical } \\
\text { Engineering } \\
\text { (wireless } \\
\text { communications) }\end{array}$ & 2,000 & $1,597^{* *}$ & * & 4 & 0 \\
\hline James Mihelcic & $\begin{array}{l}\text { Environmental } \\
\text { Engineering } \\
\text { (sustainability) }\end{array}$ & 2,000 & $1,637^{* *}$ & $\$ 517$ & 0 & 0 \\
\hline Thomas Unnasch & $\begin{array}{l}\text { Global Health } \\
\text { (tropical public } \\
\text { health) }\end{array}$ & 2,000 & 2,000 & $\$ 7,450$ & 0 & 0 \\
\hline TOTAL & & $\$ 8,000$ & $\$ 7,234$ & $\$ 16,157$ & 5 & $\$ 0$ \\
\hline \multicolumn{7}{|c|}{ Narrative Comments } \\
\hline \multicolumn{7}{|c|}{$\begin{array}{l}\text { *Dr. Gitlin submitted proposals for external funding in the amount of } \$ 548,230 \text { in FY } 10 \text { and } \\
\$ 196,712 \text { in FY11, for a total of } \$ 744,942 . \\
\text { ** Amount Expended as of } 11 / 7 / 11 \text { (ppe 10/13/11) }\end{array}$} \\
\hline
\end{tabular}

